\title{
Assessing the requirements from 'BB101' 2006 and 2018 for a naturally ventilated preparatory schools in the UK
}

\author{
Yingchun Ji, Will Swan, Richard Fitton and Terrence Fernando \\ School of the Built Environment, University of Salford, Salford, M5 4WT, United Kingdom \\ Telephone: 00441612954841 / Email: y.ji@salford.ac.uk
}

\begin{abstract}
In the UK, BB101 is the guidance document for ventilation design of school buildings. There are significant changes proposed in the new version of BB101. The aim of this paper is to examine the requirements of thermal comfort and $\mathrm{CO}_{2}$ based indoor air quality using both versions on a typical naturally ventilated preparatory school design using dynamic thermal simulations. The findings indicate that the new set of requirements on this school building designs (both thermal and $\mathrm{CO}_{2}$ concentration) are much more difficult to meet than the requirements from the old version. One of the new thermal comfort criteria may be too difficult to achieve in practice, as the target value was exceeded for all the rooms of the examined design, using both Test Reference Year and Design Summer Year weather data. The ventilation provision for the school design is believed to be adequate. With appropriate ventilation control strategies, the design is able to meet the revised $\mathrm{CO}_{2}$ concentration criteria. Further examinations of the new-criteria offrom the new guidance document are needed to make sure the chosen criteria are fit for purpose. The use of future projected Design Summer Year weather data (2020) also adds extra challenges for school building designsthe preparatory school building to meet the newly proposed adaptive thermal comfort criteria.
\end{abstract}

Key words: Building Bulletin 101, thermal comfort, $\mathrm{CO}_{2}$ concentration, Weather data, Overheating

\section{Practical Applications:}

The research presents a very first assessment of a preparatory school building design using the newly proposed BB101 guidance document. It will assist further exploration on the appropriateness of the new assessment criteria and the use of Design Summer Year weather data in order to explore the implications of the new BB101 guidelines for designers. The method adopted in the research can also be used for other building types to assess overheating in buildings when adaptive comfort criteria are recommended.

\section{Introduction}

Effective ventilation in buildings is essential in providing an acceptable indoor environment for occupants. Indoor $\mathrm{CO}_{2}$ concentration, which is directly associated with the effectiveness of ventilation, has been given particular emphasis in school buildings. Various studies have shown that the school learning environment has a significant influence on the cognitive performance of pupils. ${ }^{1,2,3}$ In the UK, Building Bulletin 101 (entitled 'Ventilation of School Buildings') 
provides a design framework for school buildings. ${ }^{4}$ Ventilation requirements from different strategies such as natural, mechanical and hybrid were outlined in this document. Public schools in the UK are often naturally ventilated. ${ }^{5}$ The use of natural ventilation has the benefits of using no extra energy and, potentially, providing better indoor air quality, however, the control of natural ventilation, driven by thermal stack effects or wind forces, is difficult, and can often result cold draughts and higher energy use in heating season. ${ }^{6}$ Mechanical ventilation has the benefits of better control of the supply of fresh air, but misses the opportunity of using natural ventilation, which is perfectly viable in the warm season. The latest update on Building Bulletin 101 (2018) aims to provide more practical guidelines in tackling energy consumption and controllability in a holistic approach for school buildings. ${ }^{7}$

The consultation of the latest update to BB101 started on the $6^{\text {th }}$ of September 2016 and the final draft was made available in January 2017. The latest release of the guidance document was in early August 2018 on the www.gov.uk website. The new BB101 is entitled 'Guidelines for ventilation, thermal comfort and indoor air quality in schools'. Recommendations on $\mathrm{CO}_{2}$ concentration based indoor air quality and thermal comfort in the new BB101 are significantly different with the BB101 (2006). Table 1 shows the summary of these changes.

Insert Table 1 here

As shown in the table, the new $\mathrm{BB} 101$ has much tighter requirements for indoor $\mathrm{CO}_{2}$ concentrations. Daily average $\mathrm{CO}_{2}$ concentration are reduced from $1500 \mathrm{ppm}$ to $1000 \mathrm{ppm}$, and for the maximum allowed $\mathrm{CO}_{2}$ concentration, the figure has been reduced from $5000 \mathrm{ppm}$ to $1500 / 2000 p p m$, with a newly introduced 20 minute limit. Unlike the previous version, which had a universal requirement for $\mathrm{CO}_{2}$ concentration, the new version introduces a clear difference for maximum allowed $\mathrm{CO}_{2}$ concentration when using specific ventilation strategies. In the case of the hybrid mode, however, the number is used for compliance purpose depends the system's operation, i.e. whether in natural ventilation mode or mechanical ventilation mode.

From a thermal comfort perspective, the changes are significant. BB101 (2006) used a single fixed temperature criterion to judge overheating occurrences (number of hours above $28^{\circ} \mathrm{C}$ ), while the new BB101 (2018) proposes an adaptive thermal comfort approach, where the indoor comfort temperatures are influenced by the outdoor running mean temperature. Relevant calculations are shown below, while more details may be found in TM52 and other standards and guidance documents. . $^{8,9,10}$

$T_{\text {comf }}=0.33 \operatorname{Max}\left(10, T_{r m}\right)+18.8$

$T_{\max }=T_{\text {comf }}+\boldsymbol{s a r}$

where $T_{\max }$ is the indoor comfort maximum temperature limit determined by the comfort temperature $T_{\text {comf }}$ and $\boldsymbol{s a r}$ (suggested acceptable range). In the above guidance documents, sar was suggested to have four different categories (I to IV) depending on the expectations of the indoor environment. For a high level of expectation (Cat. I) $\boldsymbol{s a r}= \pm 2^{\circ} \mathrm{C}$, normal expectation 
(Cat. II) $\boldsymbol{s a r}= \pm 3^{\circ} \mathrm{C}$, moderate level of expectation (Cat. III) $\boldsymbol{s a r}= \pm 4{ }^{\circ} \mathrm{C}$, and low expectation (Cat. IV) $\boldsymbol{s a r}>4^{\circ} \mathrm{C}$. In the case of new build school buildings, Cat. II is applied for spaces where teaching and learning, drama, dance and exams are held. For refurbishment projects Cat. III or IV is applied for these spaces. $T_{r m}$ is an exponentially weighted running mean of the daily mean $\left(T_{e d}\right)$ outdoor air temperature, $T_{r m}$ is defined as

$T_{r m}=(1-\alpha) T_{e d-1}+\alpha T_{r m-1}$

where, $T_{e d-1}$ and $T_{r m-1}$ are the daily mean and running mean temperature for the previous day. $T_{r m}$ is decreasingly affected by any particular daily mean temperature as time passes, the rate at which the effect of any particular daily mean temperature dies away depending on $\alpha$ (a constant between 0 and 1). The recommended value for $\alpha$ is $0.8 .^{8}$

In Table 1, the Hours of Exceedance $\left(H_{e}\right)$ are counted based on the temperature difference $\Delta T$ between the indoor operative temperature $T_{o p}$ and the comfort maximum temperature limit $T_{\max }\left(\Delta T=T_{o p}-T_{\max }\right)$. This adaptive overheating occurrence requirement is 'the number of hours $\left(H_{e}\right)$ during which $\Delta T$ is greater than or equal to one degree $(\mathrm{K})$ during the period 1st May to 30th September for the defined hours inclusive shall not be more than 40 hours'. $\Delta T$ is rounded to the nearest degree (i.e. for $\Delta T$ between 0.5 and 1.5 the value used is $1^{\circ} \mathrm{C}$, for 1.5 to 2.5 the value used is $2^{\circ} \mathrm{C}$ and so on).

The daily weighted exceedance $\left(W_{e}\right)$ is the 'daily accumulated number of hours over' for that particular day: the sum of all the rounded $\Delta T$. The third criterion limits the maximum indoor operative temperature $\left(T_{\text {upp }}\right)$ i.e., $T_{\text {upp }}$ should not be $4^{\circ} \mathrm{C}$ higher than the comfort maximum temperature limit $T_{\max }$ of a particular category.

School ventilation design has always been assessed by the Test Reference Year weather data. In the newly proposed BB101, Design Summer Year (DSY) weather was suggested to be used when examining the likely thermal comfort of schools. In the UK, both TRYs and DSYs are licensed by the Chartered Institution of Building Service Engineers (CIBSE). A DSY by definition should be always warmer than its associated TRY weather, as the latter represents a typical (or averaged) weather condition and the former represents a near extreme summer. ${ }^{15}$ However, the methodology (ranking the average dry bulb temperature from April to September and choosing the mid-year of the upper quartile to represent the near extreme) adopted in CIBSE Guide $\mathrm{J}^{11}$ experienced issues in predicting indoor warmth where, for some locations, TRY is warmer than its corresponding DSY for some building designs. ${ }^{12,13}$ Recent research and the latest CIBSE weather data release attempted to mitigate the above issue. ${ }^{14,15}$ When using the CIBSE weather data to model various building settings, it is clear that the indoor condition is not only influenced by the weather data, but also the building design itself. As a consequence, outdoor warmth defined by the given weather data does not necessarily translate into the predicted indoor warmth consistently. ${ }^{16,17}$ Nevertheless, for the CIBSE latest release of the weather data, the quadratic nature of the chosen metric (called 'weight cooling degree hour' WCDH) is broadly consistent with the relationship between the fraction of people uncomfortable and the departure from the comfort temperature. ${ }^{15}$ There were recent updates in both DSYs and TRYs discussing the details on how these weather files were generated..$^{18,19}$ 
The baseline weather data for these updated DSYs and TRYs are more up to date (1984 to 2013) and CIBSE encourages academics and industry professionals to use these files for building simulation purposes. It is fair to say the uptake of these data has not been extensive so far. One of the reasons may be that the building compliance calculations are still required to use the early release of the TRYs for consistency. There are some examples of the use of the new CIBSE weather data in evaluating overheating for open plan offices in London ${ }^{20}$, and assessing the impact of these weather data on residential building designs ${ }^{21}$, however, for school building designs these data have not been examined.

The UK's Building Schools for the Future (BSF) programme aimed to rebuild and renew 3500 secondary schools in England, with an initially anticipated budget of $f 45 \mathrm{~b} .{ }^{22}$ This was the largest single capital investment programme in 50 years in improving learning and teaching environment. Although the programme was scrapped due to cost efficiency related issues ${ }^{23}$, the link between effective teaching and learning and the environment in which it takes place appears to be well established. ${ }^{3}$ It is, therefore, important to ensure that a better indoor environment is achieved for new school designs, as well as in the retrofit of existing school buildings.

Significant changes have been made to the requirements of both $\mathrm{CO}_{2}$ concentrations and thermal comfort of school buildings between the BB101 2006 version and the BB101 2018 version. In addition, the updated weather files from CIBSE in 2016 have yet to be substantially explored in assessing school buildings. The research question raised in this paper is: what impact do these changes have on the evaluation of school building designs in terms of ventilation, thermal comfort and $\mathrm{CO}_{2}$ concentration? Using the latest weather files this research takes the first opportunity to examine the potential impact of the new BB101 (2018) requirements on an existing school design in contrast with its previous version's requirements.

\section{Methodology}

\subsection{The school model}

An existing naturally ventilated school was used in this research. The 4 storey preparatory school was designed and built in late 2008 on an existing site in London. The entrance hall is the narrow part of the building sandwiched between existing buildings (Fig 1). The teaching and learning spaces within the building include 8 classrooms, 1 computer room and 1 music room. The windows of these spaces are all facing east. The west side of the entrance hall is adjacent a major road. The built up noise level on the west side prevented the idea of opening windows, therefore roof terminals were used for ventilation. Natural ventilation is achieved through ventilation louvres, openable windows, roof terminals and stacks. A dynamic thermal model was used to assess the design BB101 2006 criteria and the design achieved a pass prior construction. This research will examine how the design performs under the newly proposed criteria compared with the former criteria. The construction details are shown in Table 2. The fabric U-values are well above the current building regulation requirements in the UK. In the Part $\mathrm{L}$ - conservation of fuel and power, the external wall $\mathrm{U}$-value requirement is $0.35 \mathrm{~W} / \mathrm{m}^{2} \mathrm{~K} .{ }^{24}$ 
The fabric U-values of this school design are close to the requirements from the voluntary Fabric Energy Efficiency Standard ${ }^{25}$ and the Passivhaus standard. ${ }^{26}$

Insert Figure 1 here

Insert Table 2 here

The detailed layout of the school is shown in Fig 2. Teaching and learning spaces on the ground floor include classrooms G.02, \& G.22 and a music room G.20; the first floor has classrooms F1.18, F1.19 \& F1.20 and a computer room F1.17; two class rooms are on the second floor: F2.07 \& F2.09; and there is one class room T3.09 on the third floor (G, F, S \& T stand Ground, First, Second \& Third Floor). Ventilation for these spaces is arranged individually, meaning there is no cross ventilation between these rooms or any other adjacent rooms. Every room has either its own designated stacks or roof terminals serving as 'exhaust'. The ventilation louvres and openable windows would, in theory, serve as 'inlets' in summer operation. Reverse air flow may happen, but the airflow only happens within a particular space, rather than causing cross contamination with other spaces. These 10 spaces, with various inlet/outlet areas, volumes, layouts, internal gains, stack heights and different types of roof terminals, will be used to carry out the compliance check against the requirements from BB101. These individually ventilated spaces are able to provide sufficient data for the proposed assessment of this research.

Insert Figure 2 here

\section{$\underline{2.2 \text { Modelling assumptions }}$}

The likely performance of the school building was assessed using the Integrated Environment Solutions (IES) Virtual Environment, which is a well-established tool for analysing the dynamic responses of a building based on the hourly input of weather data. ${ }^{27}$ The detailed internal heat gains are shown in Table 3. All rooms include an overhead projector with a gain of 250 watts, while room F1.17 also includes 23 laptops (60 watts each). Lighting is assumed $10 \mathrm{~W} / \mathrm{m}^{2}$ and the occupancy time is 09:00 to 15:30 Monday to Friday (assumptions on heat gains are based on recommendations from CIBSE Guide A. ${ }^{10}$ Maximum occupancy and all available gains in Table 3 are included to represent the worst case scenario. In reality, the overhead projectors may not be in use all the time during week days, artificial lighting may be compensated by natural daylight, and heat gains from laptops will depend on the intensity of usage. However, the worst case scenario is required when carrying out compliance calculation. The average gains in these teaching and learning spaces are around 50 to $60 \mathrm{~W} / \mathrm{m}^{2}$ except room F1.17, where a higher gain is due to the use of computers. Natural ventilation (through low level louvres or openable windows and high level stacks or roof terminals) for the design is expected to overcome the potential overheating in summer as there is no provision of mechanical ventilation for these teaching and learning spaces.

Insert Table 3 here 
Ventilation was modelled using a network airflow model, which predicts hourly ventilation rates based on prevailing driving forces of wind and buoyancy (caused by the temperature difference between inside and outside). Building ventilation is achieved by the louvres, vertical stacks with transfer grills, roof air extract terminals/louvres and openable windows. Their free areas and discharge coefficients were assumed based on their characteristics or product specifications, details of which are shown in Appendix A.

In order to mimic the likely behaviour of occupants, simple control logics were used such that the opening of the louvres and windows was determined by either the internal temperature or $\mathrm{CO}_{2}$ concentration, during the occupied period. The degree of opening for the inlet windows and louvres was varied from fully closed to fully open as the internal air temperature rose from $20^{\circ} \mathrm{C}$ to $24^{\circ} \mathrm{C}$ or the $\mathrm{CO}_{2}$ concentration rose from 800ppm to 2000ppm (ref: Table 1). During the summer period, May to September inclusive, no heating was modelled, the inlet louvres are kept open at night, as well as during weekends to achieve night cooling. Night cooling is very important in regulating the indoor thermal environment for the following day, in particular, with heavyweight construction, where large thermal mass can be used as a thermal storage to help regulate the day and night temperature variations in the indoor environment. ${ }^{6,28}$ This research focuses on the likely summer overheating, winter conditions, therefore, are not considered.

\subsection{Weather data used}

The most recent release of weather data from CIBSE was in 2016. Both Test Reference Years (TRYs) and Design Summer Years data (DSYs) were made available for 14 locations across the country: Belfast, Birmingham, Cardiff, Edinburgh, Glasgow, Leeds, London, Manchester, Newcastle, Norwich, Nottingham, Plymouth, Southampton, and Swindon. For average weather years (TRYs) the recent 2016 release is broadly consistent with the former release in 2006 as the method used for selecting individual months for TRYs are similar. Relatively large variations were observed for some locations such as Norwich, Southampton and Swindon, but these were largely attributed to the change of observation locations. ${ }^{18}$ The new metric used to select near extreme weather years for the DSYs in the 2016 release was 'weight cooling degree hours (WCDH)', defined as:

$W C D H=\sum_{i=1}^{N}\left(T_{d b t}^{i}-T_{c o m f}^{i}\right)^{2} \mid T_{d b t}^{i}>T_{c o m f}^{i}$

where $T_{\text {comf }}^{i}$ is from Eq (1) with $i$ represents individual hours, $T_{d b t}^{i}$ is the dry bulb temperature at hour $i$, representing the indoor operative temperature under the conceptual building assumption ${ }^{15}$, and $N$ is the total hours from April to September inclusive (4392 hours).

The London probabilistic DSYs were selected using the WCDHs by calculating their return periods. Three pDSYs are produced to represent different types of warm events, i.e. for London Heathrow, pDSY-1 (1989) represents a moderately warm summer; pDSY-2 (2003) has a more intense single warm spell; and pDSY-3 (1976) has a long period of persistent warmth. Higher WCDH leads to a longer return period, which indicates more severe summer warmth. For locations other than London, the same analogy was adopted, but the return periods were assessed using WCDH and two new metrics modified from the WCDH: Static WCDH \& 
Threshold WCDH. ${ }^{19}$ By definition the WCDH metric assumes that the outdoor weather dry bulb temperature equals the indoor operative temperature. The metric not only accounts for overheating occurrences, but also gives emphasis to overheating severity. Table 4 shows the WCDHs calculated for both TRYs and DSYs from the 2016 release and the previous 2006 release. Across all the 14 locations, London weather is the warmest judging by the WCDH metric. The evaluation of the school building is therefore carried out using London's weather data. The new BB101 proposed to use the future projected weather data of pDSY-1 (2020) (using the most appropriate one for the assessment location) for compliance calculation. In this research, the current pDSY-1, pDSY-2, \& pDSY-3 were also used for the chosen location to conduct the analysis. These pDSYs are the actual years in history chosen to present different characteristics of warm weather, these data are from instrumental records, considered to be more realistic than their mathematical transformed future projected data. ${ }^{15,18}$

Insert Table 4 here

\section{Results}

\subsection{Thermal responses of the school against BB101 2006 criteria}

Table 5 shows the thermal responses of the ten functional rooms within the naturally ventilated school building. The criteria used in table 5 are from the BB101 2006 version. In this version the Test Reference Years (TRYs) were required to assess school building designs. The data presented in the table using Design Summer Year (DSYs) weather are for cross comparison purposes. For the 'number of hours over $28^{\circ} \mathrm{C}$ ' criterion, all the functional spaces of the school design meet the requirement by a relatively large margin when using the TRY weathers. Even with the near extreme weather conditions (the pDSYs) majority of the spaces are well within the target requirement (less than 120 hours). For some of the pDSYs, the music room G20, classroom G22 \& computer room F117 failed to meet this criterion (bold numbers in Table 5 - Criteria 1). For Criteria 3 - the 'average internal/external temperature difference' most of the spaces meet the $\leq 5^{\circ} \mathrm{C}$ target requirement. The computer room F117 consistently fails this criterion with one of the TRYs (TRY16), due to its high internal heat gains (Table 3). Classroom S209 is the second worst against Criteria 2, followed by classroom F118. For the Criteria 3, all the rooms failed to meet this criterion when DSYs were used. Even with TRYs, five out of the ten evaluated spaces exceeded the target requirement. The judgement on a school design is based on the principle that - 'the school will not suffer from overheating if two out of these three criteria are met'. With the given design, data in Table 5 illustrate that a full pass is achieved when using TRY 2006, while for all the other weather data evaluated including TRY 2016, there are always some spaces that fail to meet the standard requirement.

It is worth noting that the 'average internal/external temperature difference (Criteria 2)' in Table 5 is the average of the whole occupancy time from May to September. BB101 2006 does not clearly define whether the average is for the internal/external temperature difference during the whole occupancy time or the maximum 'daily' average internal/external temperature difference. If it were for the whole summer time, from May to September, this criterion could not capture the overheating severity at a daily level. For example, collectively, the average internal/external temperature difference meets the targets, but this criterion would not guarantee there are days when the internal/external temperature difference could be significantly higher than the given target, causing discomfort for occupants. If the criterion were for the maximum 'daily' average difference between internal and external temperature, it could potentially be misleading for overheating assessments in school designs. Figure 3 
shows the internal (blue line) and external (red line) temperatures for a typical cooler day and a typical warmer day, using room F117 as an example. It is evident that a higher 'daily' average internal/external temperature difference can be found on a cooler day $\left(11.10^{\circ} \mathrm{C}\right.$ on the $4^{\text {th }}$ of May) rather than a warmer day $\left(6.38^{\circ} \mathrm{C}\right.$ on the $12^{\text {th }}$ of August), when overheating is likely to happen. This implies that the maximum 'daily' average internal/external temperature difference could happen during a particular cooler day when overheating is unlikely to happen (as in Figure 3 left, the maximum temperature is less than $22^{\circ} \mathrm{C}$ ), which clearly contradicts the purpose of the criterion in assessing overheating. For cooler days, the outdoor daily average dry-bulb temperature during occupancy is low $\left(8.73^{\circ} \mathrm{C}\right)$, but the average indoor air temperature during occupancy is relatively high $\left(19.83^{\circ} \mathrm{C}\right)$ due to the internal gains (ref: Table 3 ), solar gains and overall low thermal transmittances of construction materials used (ref: Table 2). As shown in Figure 3, the ventilation rate during occupancy between the two days is quite different, with low ventilation in the cooler day and higher ventilation in the warmer day. This is due to the impact of the ventilation control strategy on internal air temperature as explained in section 2.2. The low ventilation in a cooler day is also a key reason for a high average internal/external temperature difference.

Insert Figure 3 here

Insert Table 5 here

\subsection{Thermal responses of the school against BB101 2018 criteria}

As shown in Table 6, the same modelling outputs were examined against the new adaptive thermal comfort based criteria from the newly proposed BB101 2018. Bold numbers in the table indicate that the target values are not met. For the 'Hours of Exceedance' criterion using current Design Summer Year weathers (pDSYs) and pDSY-1 2020, all the evaluated rooms failed to meet this criterion for weather locations such as Gatwick pDSY-3, Heathrow pDSY-2, pDSY-3, and the London Weather Centre pDSY-3. For the pDSY-1 at the three locations in London, there are 5 or 6 rooms where their 'hours of exceedance' are below the target value. For pDSY-1 2020, 4 rooms at Gatwick, 1 room at Heathrow and 3 rooms at London weather centre are below 40 hours. This may indicate that with pDSY-1 (and its immediate projections), which is a 'moderately warm summer', there is scope to work towards achieving a pass for all the spaces with this criterion. However, it would be much tougher to achieve a pass for pDSY-2, which has a more intense single warm spell, \& pDSY-3, which has a long period of persistent warmth, among all three locations in London. It would be much easier to meet this criterion if Test Reference Year weathers were used. For both TRY 2006 and TRY 2016, only one or two rooms failed to meet the 40 hours target.

For Criteria 2 in table 6 - daily weighted exceedance, all the rooms with all the weather data overwhelmingly failed to meet this criterion by a much larger margin. Broadly, $W_{e}$ results from pDSYs are far larger than those from the TRYs (please note: the London TRYs are Heathrow based) which is expected by their definitions. This criterion is to assess the overheating severity on a daily basis. Examining both TRYs and pDSYs weather data over the summer period from May to September inclusive, it is clear all the weather data have warm spells where the outdoor temperatures are high. These warm spells, moderate or severe, will result a higher daily weighted exceedance. This will make passing this criterion extremely difficult. The pDSY-2 weather data by definition have 'a more intense single warm spell'. An intense warm spell could potentially lead to a higher $W_{e}$ as $W_{e}$ is calculated on a daily basis. This is certainly the case for Heathrow and the London Weather Centre, as all the calculated $W_{e}$ values from 
the two locations for pDSY-2 are higher than the $W_{e}$ values calculated from their corresponding pDSY-1 and pDSY-3. However, this trend is less obvious at Gatwick as only 3 rooms $(F 118,119,120)$ follow the trend by a relatively small margin. All the other rooms, either its pDSY-1, or pDSY-3, or both result higher $W_{e}$ values. The resulted $W_{e}$ values for pDSY12020 - the future projection of pDSY-1 are consistently higher than its corresponding pDSY-1 and, in many cases, even higher than pDSY-2 and pDSY-3, due to the emphasis of warm spells when future weather data were generated.

The third criterion is an alternative way of assessing overheating severity. It assesses the temperature difference $(\Delta T)$ between the maximum operative temperature $T_{\text {upp }}$ and the maximum allowed comfort temperature $T_{\max }$. Apart from the pDSY-1 weather data of London Weather Centre and Heathrow, which has 3 rooms and 1 room where $\Delta T$ is at $4 \mathrm{~K}$, higher $\Delta T$ values were resulted by all the other pDSYs weathers for all the rooms, including the pDSY-1 2020. Collectively higher $\Delta T$ values were predicted for all the rooms when using the pDSY-2 weather from the three locations compared with their corresponding pDSY-1 \& pDSY-3 at these locations. This again emphasizes the influence of the single intense warm spell on the overheating severity for any given time when maximum $\Delta T$ is resulted across the whole summer. The temperature difference $\Delta T$ (as well as the daily weighted exceedance $W_{e}$ ) values will inevitably be influenced by the 'intensity' of the particular warm spell within pDSY-2 weathers.

Out of these three criteria, if 'any two of them exceeded the target values, the building design would be deemed to be overheating'. With the suggested use of CIBSE Design Summer Year weather data (pDSY-1 2020) in BB101 2018, the design examined in this paper indeed causes overheating, which is clearly evidenced in Table 6 . The requirement from Criteria 2 is very hard to meet. Meeting the other two criteria can be possible for some spaces, such as rooms G02 \& F119, with moderately warm weather pDSY-1 at London Weather Centre, and room S309 for pDSY-1 at both London Heathrow and Weather Centre. However, the whole building design as is, overwhelmingly fails for pDSY-1 2020 and all the other examined pDSYs. For the two TRYs examined, small margins need to be managed (such as room G20, G22, F117 \& F118) before the design can pass the overheating assessment. For the three examined locations in London, the Weather Centre represents inner urban climate, Gatwick represents rural climate, and Heathrow represents intermediate urban and suburban locations. Broadly speaking, weather data from the London Weather Centre does seem to be warmer. This is expected due to inner urban heat island effects. ${ }^{20}$

Insert Table 6 here

\section{$\underline{3.3} \mathrm{CO}_{2}$ concentration against both versions of BB101 criteria}

Table 7 shows the $\mathrm{CO}_{2}$ concentration data against the requirements from the old and newly proposed BB101. For the 'Maximum $\mathrm{CO}_{2}$ concentration', the new target of $\leq 2000 \mathrm{ppm}$ is much stricter than the previous target of $\leq 5000 \mathrm{ppm}$. With the given school design and the examined TRYs and pDSYs, this criterion can be met without much further effort on the design. Only one room (G 02) fails to meet this with some of the examined weather data. For the 'maximum daily average $\mathrm{CO}_{2}$ concentration' it is obviously a different story. The majority of the examined rooms failed to meet the newly proposed requirement in BB101 $2018(\leq 1000 \mathrm{ppm})$. It is worth noting that if the criterion of $\leq 1500 p p m$ from BB101 2006 were used, all the rooms would 
have passed. The newly proposed requirements on $\mathrm{CO}_{2}$ concentration are indeed much more stringent than the previous version and a typical school design could fail easily.

The school design used in this research is a typical natural ventilation design. It does provide adequate provision to bring down $\mathrm{CO}_{2}$ concentration through ventilation. As illustrated in Figure 4 (choosing the same dates as in Figure 3 ), the ventilation rate on the warmer day $\left(12^{\text {th }}\right.$ August) can be as high as 500l/s during occupancy. With only 24 occupants in total (room F117, 1 adult and 23 pupils, see table 3 ), the ventilation rate per person is more than $20 \mathrm{l} / \mathrm{s} / \mathrm{p}$, the resulted $\mathrm{CO}_{2}$ concentration is less than $650 \mathrm{ppm}$. However, for the cooler day ( $4^{\text {th }}$ of May) the ventilation rate is less than $200 \mathrm{l} / \mathrm{s}$, the average $\mathrm{CO}_{2}$ concentration is over $1000 \mathrm{ppm}$. The lower ventilation on the cooler day is due to the ventilation control by referencing internal air temperature and $\mathrm{CO}_{2}$ concentration (The degree of opening for the inlet windows and louvres was varied from fully closed to fully open as the internal air temperature rose from $20^{\circ} \mathrm{C}$ to 24 ${ }^{\circ} \mathrm{C}$ or the $\mathrm{CO}_{2}$ concentration rose from 800ppm to 2000ppm, see section 2.2). This strategy was set to meet the BB101 2006 requirement. If the control for $\mathrm{CO}_{2}$ concentration were, for example, $600 \mathrm{ppm}$ to $1000 \mathrm{ppm}$, the inlet windows and louvres would have been fully opened on the $4^{\text {th }}$ of May (Figure 4, left). With the high internal/external temperature difference, higher ventilation could be achieved (this affirms the provision of ventilation is adequate enough when necessary). However, the indoor air temperature could be brought down to, or much lower than, the comfort temperature threshold $\left(22.1^{\circ} \mathrm{C}\right.$, ref: $\mathrm{Eq}(1)$ when the running mean $T_{r m}$ is less than $10^{\circ} \mathrm{C}$ ). Therefore, a delicate balance between $\mathrm{CO}_{2}$ concentration and thermal comfort needs to be managed through more appropriate natural ventilation control strategies.

Insert Figure 4 here

Insert Table 7 here

\section{Discussion}

Apart from the radical changes in $\mathrm{CO}_{2}$ concentration requirements and the use of adaptive thermal comfort over fixed temperature criteria to judge overheating, the new BB101 also emphasizes the significance of the indoor air quality (IAQ) from other pollutants. It considers a wide range of potential pollutants from both the indoor and outdoor environment. Relevant national and international standards are referenced and explicit requirements are given on controlling the permitted level of these pollutants. The old version BB101 also discussed IAQ by referencing various pollutants but the given requirements were not as detailed as the new BB101. One thing in common from both old and new BB101 is that there are no recommendations on how pollutants based compliance calculations should be made when required. Specialized air pollutants modelling tools and the dynamic thermal simulation tools (such as the one used in this research) may be used together to provide a more holistic assessment for new school building designs under the new guidance document.

The primary focus of this research is to evaluate the impact from the newly proposed BB101 on the overheating assessment of an existing school building design. It is not about proposing interventions to achieve the relevant target criteria. The chosen school design is a typical natural ventilation design. The overheating assessment of the design can achieve a pass using 
the requirements from BB101 2006. However, the design will fail using the newly proposed criteria from BB101 2018. As discussed in section 3.3, the indoor $\mathrm{CO}_{2}$ concentrations will not be an issue, if the appropriate control strategies are used with the given design. For thermal comfort criteria, more effort would be needed if the design is to achieve a pass under the new BB101 requirements.

\subsection{Overheating occurrence criteria}

Criteria 1 from both versions of BB101 account for overheating occurrence: how many hours (times) the indoor temperature is over the threshold during occupancy. For the 2006 version, the indoor air temperature is assessed against a fixed temperature threshold of $28^{\circ} \mathrm{C}$; while for the newly proposed version, the indoor operative temperature is assessed against adaptive thermal comfort temperature, which varies with outdoor weather dry bulb temperature. In summer time, the indoor operative temperature tends to be slightly higher than the indoor air temperature due to the relatively high mean radiant temperature (at low indoor air movement condition, the operative temperature is the average of the air temperature and the mean radiant temperature). The difference is rarely more than $0.5^{\circ} \mathrm{C}$ in summer time for free running conditions (no heating/cooling). When calculating the hours of exceedance $\left(H_{e}\right)$, the temperature difference was rounded to the nearest degree (see section 1), so the slight difference between the indoor air temperature and the operative temperature becomes irrelevant. The data for Criteria 1 from Tables $5 \& 6$ are plotted in Figure 5 to examine whether there is a correlation between the two overheating occurrence criteria. As shown in Figure 5 , the data do seem to be well correlated. Previous research on the two similar criteria has also shown correlations between variations of designs against the same weather data. ${ }^{28}$ The current data were from 10 individual rooms and 12 different weather data; the resulting overheating occurrences between the two criteria are correlated more strictly due to how $H_{e}$ is calculated. In terms of the likelihood of achieving a pass for the two overheating occurrence criteria, it is obvious that the new criterion from BB101 2018 using Design Summer Year (pDSYs) weather data is much more difficult to achieve (with more points beyond the target 40 degree hours compared with the number of points beyond the 120 hours over $28^{\circ} \mathrm{C}$ ).

Insert Figure 5 here

\subsection{Overheating severity criteria}

The second criterion (daily weighted exceedance) in Table 6 assesses overheating severity by counting the sum of the all the rounded $\Delta T$. The maximum daily weighted exceedance $W_{e}$ will naturally happen on the peak day, which means this criterion is in line with the Criteria 3 (maximum internal air temperature - the peak day) in Table 5. Figure 6 illustrates the peak date (29 $9^{\text {th }}$ June) for room F117 using London Heathrow pDSY-3 (Heathrow 1976). The peak indoor operative temperature is $37.49^{\circ} \mathrm{C}$ (peak air temperature $37.45^{\circ} \mathrm{C}$ as in Table 5 Criteria 3) at 2:30pm, while the peak outdoor dry bulb temperature is $33.8^{\circ} \mathrm{C}$ at $4: 00 \mathrm{pm}$. The cloud cover increased after 1:00pm which leads to reduced solar radiation gain for the room. The reduced solar gain was the reason why the peak indoor operative temperature happens before the peak outdoor dry bulb temperature. The maximum $\mathrm{CO}_{2}$ concentration on this hottest day is 
less than 650ppm which means the ventilation is adequate during occupancy. Using equations 1 to 3 , the daily mean, running mean and indoor comfort maximum temperature limit $T_{\text {max }}$ can be calculated at $24.15^{\circ} \mathrm{C}, 24.28^{\circ} \mathrm{C} \& 29.81^{\circ} \mathrm{C}$ respectively ( $T_{\max }$ is dashed line on the graph). The operative temperatures above the dashed line during occupancy can be added up to calculate $W_{e}$. For this case, $W_{e}$ equal 40 degree hours. The upper limit temperature $\left(T_{\text {upp }}\right)$ is also an overheating severity criterion. On this peak date, $\Delta T=T_{\text {upp }}-T_{\max }=37.49^{\circ} \mathrm{C}-29.81^{\circ} \mathrm{C}=$ $7.68^{\circ} \mathrm{C}$ which will be rounded up to $8^{\circ} \mathrm{C}$ as in Table 6 (Criteria 3).

Due to the nature how $T_{\max }$ is calculated, $T_{\max }$ will always equal or be above $25.1^{\circ} \mathrm{C}$. Using $T_{\max }$ as a baseline to calculate daily weighted exceedance avoids the possibility that a higher $W_{e}$ is found on a cooler day, which could happen when calculating maximium 'daily' internal/external temperature difference, as discussed in section 3.1. Therefore, $W_{e}$ is truly reflecting the maximum extent of overheating on a particular date.

Criteria 3, in Table 5, is very difficult to achieve, especially for those pDSY weathers (for cross comparison purposes only, they are not meant to be used in BB101 2006 version). While Criteria 3, in Table 6, is relatively less difficult to achieve. Although this criterion also assesses the maximum indoor operative temperature which is similarly with the maximum indoor air temperature, the difference is that Criteria 3 in Table 6 assesses the temperature difference $\Delta T$ rather than the absolute figure of the maximum temperature. Using the adaptive comfort approach, $T_{\max }$ varies with outdoor daily running mean temperatures, which makes the target $\Delta T$ relatively easier to achieve.

Insert Figure 6 here

\subsection{Limitations and future work}

BB101 compliance calculations have always been carried out using dynamic thermal simulation tools in the past, primarily focused on thermal comfort criteria and $\mathrm{CO}_{2}$ concentration requirements. Such calculations are inevitably influenced by various model assumptions, such as approximations on building facades, operational schedules and the use of weather data. There is increasing research evidence showing the discrepancies between predicted and in-use performance - the so called 'performance gap'. ${ }^{29,30}$ It would be beneficial that such evaluations can be validated by field measurements to improve the confidence of the modelling outputs. However, field measurements are rare and often not comprehensive enough for detailed validation purposes. The validation of the modelling outputs of this research were not possible due to the lack of monitoring data of the exisiting building. This represents an opportunity to extend this work in the future.

The new BB101 is not only introducing tighter requirements on thermal comfort and $\mathrm{CO}_{2}$ concentration, but are also putting great emphasis on the IAQ related polulltant control. Explicit requirements are given against various pollutants, which may cause adverse impacts on occupants. It is evident from this research that designs that comply with the BB101 2006 criteria, as might be expected, do not necessarily meeting the criteria of the new BB101 2018. For the natural ventilation design of school buildings, systematic assessments are needed to 
examine the new criteria, and interventions (such as shading, high thermal mass structure, phase change materials, appropriate control on night purging, etc) may well be needed in order to make sure the relevant criteria are met. It is likely that natural ventilation on its own may not be able to maintain the level of comfort needed; mixed mode or demand controlled mechanical ventilation may be needed as a consequence from the tighter requirements of the new BB101. For a more holistic assessment of the new guidance document, the indoor air quality of new designs also needs to be evaluated, which may involve the use of specilized pollutant modelling tools.

\section{Conclusions}

This work sets out to evaluate the new BB101 requirements on school building designs against the requirements from its early version. Both overheating and $\mathrm{CO}_{2}$ concentrations were examined on an existing naturally ventilated school design. 10 classrooms with various internal heat gains levels were included for the analysis. The used weather data are from London, where overheating in classrooms is more likely to happen in the UK. The 12 weather data from the latest CIBSE release include the Test Reference Years from Heathrow, and Design Summer Years from Gatwick, Heathrow, London Weather Centre and their corresponding projected weather in 2020. Both sets of requirements from BB101 2006 and 2018 were assessed using the school design and there are 120 data outputs in total for each criterion. The data presented in this research clearly indicates that meeting the new requirements from BB101 2018 are more difficult than those of the BB101 2006 for natural ventilation school designs. The school model can achieve a pass when using the requirements from BB101 2006 with the relevant Test Reference Year weather. However, in many respects, the design fails to meet the requirements from BB101 2018 when the current and future projected Design Summer Year weather data were used.

The adaptive thermal comfort based criteria from BB101 2018 include the 'Hours of Exceedance $-H_{e}$ ', 'daily weighted exceedance $-W_{e}$ ' and ' $\Delta T$ ' (represents the difference between the maximum operative temperature $T_{\text {upp }}$ and the corresponding maximum allowed comfort temperature $T_{\max }$ ). For $H_{e}$, there are only a few rooms, when using pDSY-1 (a moderate warm summer) in London, that can meet the 40 degree hours target. By comparison, when counting the number of hours over $28^{\circ} \mathrm{C}$ using Test Reference Year weathers - the requirement from BB101 2006, all the rooms examined are well below the target 120 hours. From the overheating occurrence perspective, the new requirement is more difficult to meet when compared with the earlier requirement.

For $W_{e}$, the results show that there is no likelihood that this criterion can be met for the school design examined. $W_{e}$ in Table 6 shows the school design exceeded its target value for all the rooms with all the weather data examined (120 data), often by a large margin. This is due to the nature of how $W_{e}$ is calculated. Even using TRY weather data, the minimum $W_{e}$ calculated are 10 degree hours which are still much larger than the target 6 degree hours. This raises the question on the practicality of using this criterion to assess overheating in schools. One can safely assume if a design were able to meet this criterion, the other two criteria should have 
been well met automatically. The criterion 'average internal/external temperature difference' from BB101 2006 is also deemed unrealistic in assessing overheating. When the 'average difference' is for the whole summer, it is much easier to achieve but it fails to capture the likelihood of overheating at daily level. If a maximum 'daily' difference between average internal and external temperature were examined, the criterion could be misleading as a cooler day can result a larger daily internal/external temperature difference, but overheating is unlikely to happen.

For $\Delta T$ criterion, although it assesses the maximum indoor operative temperature $-T_{u p p}, \Delta T$ is not only determined by $T_{\text {upp }}$ but also $T_{\max }$, which varies with the running mean outdoor temperature. For this reason, the $\Delta T$ criterion is relatively more achievable when compared with the 'maximum internal temperature' criterion from BB101 2006, which are well evidenced by Criteria 3 in Table 5 \& Table 6.

The $\mathrm{CO}_{2}$ concentration related IAQ criteria do not seem to add much difficulty for school natural ventilation design, although the requirements are stricter in the new version of BB101. Higher $\mathrm{CO}_{2}$ concentration tends to occur on cooler days, where the ventilation is restricted due to low indoor temperature. This could be easily rectified by providing more appropriate ventilation control strategies, as the given design provides enough provision for ventilation when needed.

The new BB101 was published in August 2018. The discussions from this research could be useful in understanding the assessment criteria for school building designs. If assessment criteria were unrealistically strict, few school designs could meet those using naturally ventilated approaches. There is the potential that the industry may stay away from natural ventilation design on this basis. This will undermine the efforts in promoting natural ventilation to achieve energy conservation and better indoor air quality. However, if the requirements are too easy to achieve, naturally ventilated schools will be built, but they will fail to maintain thermal comfort for occupants in practice. This research represents an initial investigation into the proposed guidance document. However, more effort is needed to evaluate these criteria in terms of how practical they are in guiding the future school designs. Clearly from this research, one of the new adaptive thermal comfort criteria - daily weighted exceedance $W_{e}$ can be arguable as it may be too difficult to achieve due to the nature of how it is calculated. It is also evident that a design is more likely to meet the standard requirements using 'a moderate warm summer' and its projected 2020 counterpart than its corresponding two pDSYs which have either 'a single intense warm spell' or 'a long persistent warmth'.

\section{Appendix A}

Insert Table A1 here

\section{References}


${ }^{1}$ Coley D, Greeves R \& Saxby B. The effect of low ventilation rates on the congnitive function of a primary school class. International Journal of Ventilation, 2007, 6(2), pp. $107-112$.

${ }^{2}$ Bako-Biro Z et al. Ventilation rates in schools and pupils' performance. Building and Environment, 2012, Volume 48, pp. 215-223.

${ }^{3}$ Barrett P, Davies F, Zhang Y \& Barrett L. The impact of classroom design on pupils' learning: Final results of a holistic, multi-level analysis. Building and Environment, 2015, Volume 89, pp. 118-133

${ }^{4}$ BB101 2006. Ventilation of School buildings, 2006, ISBN 011-2711642. s.1.:s.n.

${ }^{5}$ Jenkins D P, Peacock A D \& Banfill P. Will future low-carbon schools in the UK have an overheating problem. Building and Environment, 2009, Volume 44, pp. 490-501.

${ }^{6} \mathrm{Ji}$ Y, Lomas K J \& Cook M J. Hybrid ventilation for low energy building design in south China. Building and Environment, 2009, Volume 44, pp. 2245-2255.

${ }^{7}$ BB101, 2018. Guidelines on ventilation,thermal comfort and indoor air quality in schools. Version 1, August 2018, Education \& Skill Funding Agency, https://www.gov.uk/government/publications

[Accessed September 2018]

${ }^{8}$ BS EN 15251 2007. Indoor environmental input parameters for design and assessment of energy performance of buildings addressing indoor air quality, thermal environment, lighting and acoustics. 2007, s.1.:BSI, EN.

${ }^{9}$ CIBSE TM52, 2013. The limits of thermal comfort: avoiding overheating in European buildings. London: The Charted Institution of Building Services Engineers.

${ }^{10}$ CIBSE Guide A 2015. Environmental design. London: Charted Institution of Building Services Engineers

${ }^{11}$ CIBSE Guide J 2002. Weather, solar and illuminance data. London: The Charted Institution of Building Services and Engineers.

${ }^{12}$ Smith S \& Hanby V. Methodologies for the generation of design summer years for building energy simulation using UKCP09 probabilistic climate projections. Building Services Engineer Research \& Technology, 2012, Volume 33, pp. 9-17.

13 Jetsch M, Levermore G \& Parkinson J. Limitations of the CIBSE design summer year approach for delivering representative near-extreme summer weather conditions. Building Serv. Eng. Res. Technol., 2013, Volume 35, pp. 155-169.

${ }^{14}$ Jentsch M, Eames M. \& Levermore J. Generating near-extreme Summer Reference Years for building performance simulation. Building Serv. Eng. Res. Technol., 2015, Volume 36, pp. 701-727.

15 CIBSE TM49 2014. Design Summer Years for London. London: The Charted Institution of Building Services Engineers.

${ }^{16}$ Ji Y, Zhang Y, Korolija I \& Futcher J.. Design summer year weather - outdoor warmth ranking metrics and their numerical verification. 2016, Building Serv. Eng. Res. Technol., 37(6), pp. 639-663.

$17 \mathrm{Ji}$ Y, Korolija I \& Zhang Y. Thermal responses of single zone offices on existing near-extreme summer weather data. Building Simulation, 2017, 11(1), pp. 15-35.

${ }^{18}$ Eames M, Ramallo-Gonzalez A \& Wood M. An update of the UK's test reference year: The implications of a revised climate on building design. Building Serv. Eng. Res. Technol., 2016, 37(3), pp. 316-333.

${ }^{19}$ Eames,M. An update of the UK's design summer years: Probabilistic design summer years for enhanced overheating risk analysis in building design. Building Serv. Eng. Res. Technol., 2016, 37(5), pp. 503-522.

${ }^{20}$ Virk G, Mylona A, Mavrogianni A \& Davies M. Using the new CIBSE design summer years to assess overheating in London: Effect of the urban heat island on design. Building Serv. Eng. Res. Technol., 2015, 36(2), pp. 115-128.

${ }^{21}$ Amoako-Attah J \& B-Jahromi A. The impact of Different Weather Files on Lond Detached Residential Building Performance. Sustinability, 2016, 8(1194), pp. 1-18.

22 Mahony P, Hextall I \& Richardson M. 'Building Schools for the Future': Reflections on a new social architecture. Journal of Education Policy, 2011, 26(3), pp. 341-360.

${ }^{23}$ Mahony P \& Hextall I. 'Building Schools for the Future': 'transformation' for social justice or expensive blunder?. British Educational Research Journal, 2012, 39(5), pp. 853-871.

${ }^{24}$ Part L 2010. Conservation of fuel and power. s.1.:HM Government.

${ }^{25}$ Zero Carbon Hub 2009. Definning a Fabric Energy Efficiency Standard for Zero Carbon Homes.

London: Zero Carbon Hub.

${ }^{26}$ Passivhaus 2010. Passivhaus primer: Designer's guide - A guide for the design team and local authorities. s.1.:Building Research Establishment. 
${ }^{27}$ IESVE 2017. Integrated Environmental Solutions Virtual Environment. Available at: www.iesve.com [Accessed November 2017].

${ }^{28}$ Lomas K \& Ji Y. Resilience of naturally ventilated buildings to climate change: advanced natural ventilation and hospital wards. Energy and Buildings, 2009, Volume 41, pp. 629-653

${ }^{29}$ Menezes AC, Cripps A, Bouchlaghem D \& Buswell R. (2012). Predicted vs. actual energy performance of non-domestic buildings: Using post-occupancy evaluation data to reduce the performance gap. Applied Energy 97 (2012) p. 355-364

${ }^{30}$ Marshall A., Fitton R., Swan W., Farmer D., Johnston D., Benjaber M., Ji Y. 2017. Domestic building fabric performance: Closing the gap between the in situ measured and modelled performance, Energy and Buildings, Volume 150, Pages 307-317, ISSN 0378-7788, https://doi.org/10.1016/j.enbuild.2017.06.028 
Table 1 The key differences in IAQ and thermal comfort between the old BB101 and new BB101 for school teaching and learning spaces

\begin{tabular}{|c|c|c|c|}
\hline & BB101 (2006) & \multicolumn{2}{|c|}{ BB101 (20162018) } \\
\hline \multirow{2}{*}{$\begin{array}{l}\text { Ventilation } \\
\text { requirement } \\
\text { (l/s/p-litre } \\
\text { per second } \\
\text { per person) }\end{array}$} & $\begin{array}{l}\text { Natural, Mechanical or Hybrid } \\
\text { ventilation }\end{array}$ & Mechanical & Natural \\
\hline & $\begin{array}{ll}\text { - } & \text { minimum: } 3 \mathrm{l} / \mathrm{s} / \mathrm{p} \\
\text { - } & \text { Minimum daily average: } 5 \mathrm{l} / \mathrm{s} / \mathrm{p} \\
\text { - } & \text { System capacity - ability to provide } \\
& \text { minimum } 8 \mathrm{l} / \mathrm{s} / \mathrm{p} \text { during occupancy }\end{array}$ & 8 to $9 l / s / p$ & $5 \mathrm{l} / \mathrm{s} / \mathrm{p}$ \\
\hline $\begin{array}{l}\mathrm{CO}_{2} \\
\text { concentration }\end{array}$ & $\begin{array}{l}\text { - Average during occupancy } \\
\leq 1500 \mathrm{ppm} \\
\text { - Maximum } \leq 5000 \mathrm{ppm} \\
\text { - Ability to adjust the concentration } \\
\text { to } 1000 \mathrm{ppm} \text {. }\end{array}$ & $\begin{array}{l}\text { - Average: } \\
\text { s1000ppm } \\
\text { Maximum: } \\
\leq 1500 p p m \\
\text { for more than } \\
20 \text { minutes }\end{array}$ & $\begin{array}{l}\text { - Average: } \\
\text { s1000ppm } \\
\text { Maximum: } \\
\leq 2000 \mathrm{ppm} \text { for } \\
\text { more than } 20 \\
\text { minutes }\end{array}$ \\
\hline $\begin{array}{l}\text { Thermal } \\
\text { comfort } \\
\text { criteria - } \\
\text { (two out of } \\
\text { three criteria } \\
\text { need to be } \\
\text { met). }\end{array}$ & $\begin{array}{l}\text { - Number of hours the air } \\
\text { temperature over } 28^{\circ} \mathrm{C} \leq 120 \\
\text { - Average internal to external } \\
\text { temperature difference } \leq 5^{\circ} \mathrm{C} \\
\text { - Maximum internal air temperature } \\
\leq 32^{\circ} \mathrm{C}\end{array}$ & \multicolumn{2}{|c|}{ 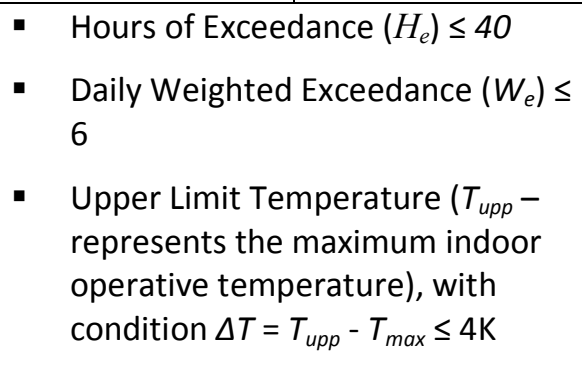 } \\
\hline Weather file & Test Reference Year & \multicolumn{2}{|c|}{ Design Summer Year } \\
\hline Occupancy & 9:00 to $15: 30 / 1^{\text {st }}$ May to $31^{\text {st }}$ Sept & $9: 00$ to $16: 00 / 1^{\text {st }} \Lambda$ & May to $31^{\text {st }}$ Sept \\
\hline
\end{tabular}

Table 2 Construction details and the overall thermal transmittance: U-values

\begin{tabular}{|c|c|c|}
\hline $\begin{array}{l}\text { Construction } \\
\text { Type }\end{array}$ & $\begin{array}{l}\text { Construction Detail } \\
\text { (outside to inside) }\end{array}$ & $\begin{array}{l}\text { U-value } \\
\left(\mathrm{W} / \mathrm{m}^{2} \mathrm{~K}\right)\end{array}$ \\
\hline External Glazing & $6 \mathrm{~mm}$ glazed panel $+16 \mathrm{~mm}$ Argon filled gap $+6 \mathrm{~mm}$ glazed panel & 1.09 \\
\hline Zinc Roof & $\begin{array}{l}\text { Lightweight metallic cladding } 3 \mathrm{~mm}+\text { Plywood (Lightweight) } 45 \mathrm{~mm}+\text { Glass Fibre } \\
\text { Quilt } 200 \mathrm{~mm}+\text { Weatherboard } 90 \mathrm{~mm}+\text { EPS Slab } 25 \mathrm{~mm}+\text { Gypsum Plasterboard } \\
25 \mathrm{~mm}\end{array}$ & 0.14 \\
\hline Sarnafil Roof & $\begin{array}{l}\text { Lightweight Metallic Cladding 3mm + Dense EPS Slab Insulation 200mm + Cast } \\
\text { Concrete (Dense) } 200 \mathrm{~mm}+\text { Cavity } 200 \mathrm{~mm}+\text { Acoustic Tile HF-ES } 10 \mathrm{~mm}\end{array}$ & 0.12 \\
\hline Internal wall & $\begin{array}{l}\text { Fiberboard - Tile \& Lay-in Panels + (Gypsum/Plaster Board + Glass-Fibre Quilt } \\
\text { Plywood (Lightweight) + Glass-Fibre Quilt + Gypsum/Plaster Board) + Fiberboard - } \\
\text { Tile \& Lay-in Panels }\end{array}$ & 0.29 \\
\hline External Wall & $\begin{array}{l}\text { Plywood Sheathing 36mm + Class-Fibre Quilt 250mm + Plywood (Lightweight) } \\
18 \mathrm{~mm}+\text { Gypsum Plastering 30mm }\end{array}$ & 0.15 \\
\hline $\begin{array}{l}\text { Ground Exposed } \\
\text { Floor }\end{array}$ & $\begin{array}{l}\text { London Clay } 750 \mathrm{~mm}+\text { Cast Concrete (Dense) } 200 \mathrm{~mm}+\text { Screed } 10 \mathrm{~mm}+\text { Dense EPS } \\
\text { Slab insulation } 40 \mathrm{~mm}+\text { EPS Slab } 30 \mathrm{~mm}+\text { Fibreboard } 20 \mathrm{~mm}+\text { Rubber Tiles } 6 \mathrm{~mm}\end{array}$ & 0.27 \\
\hline $\begin{array}{l}\text { Intermediate } \\
\text { Floors }\end{array}$ & $\begin{array}{l}\text { Cast Concrete (dense) } 200 \mathrm{~mm}+\text { Screed } 10 \mathrm{~mm}+\text { EPS Slab } 30 \mathrm{~mm}+\text { Fibreboard } \\
20 \mathrm{~mm}+\text { Rubber tiles } 6 \mathrm{~mm}\end{array}$ & 0.62 \\
\hline
\end{tabular}


Table 3 Internal heat gains and occupancy (G, F, S \& T mean Ground, First, Second \& Third Floor ${ }_{2}$ data were taken from design specifications)

\begin{tabular}{|c|c|c|c|c|c|c|c|}
\hline \multirow{2}{*}{ Room } & \multicolumn{3}{|c|}{ Internal heat gains } & FA & \multicolumn{2}{|c|}{ Total Gain } & \multirow{2}{*}{$\begin{array}{c}\text { Occupancy } \\
\text { Time }\end{array}$} \\
\hline & During occupancy & equipment & Lighting & $\left(m^{2}\right)$ & $(W)$ & $\left(\mathrm{W} / \mathrm{m}^{2}\right)$ & \\
\hline G.02 & 1 Adult + 19 Pupils & \multirow{3}{*}{$250 W$} & \multirow{10}{*}{$10 \mathrm{~W} / \mathrm{m}^{2}$} & 35.6 & 2120.6 & 59.5 & \multirow{10}{*}{$\begin{array}{c}\text { 09:00 to } 15: 30 \\
\text { Mon To Fri }\end{array}$} \\
\hline G.20 & 1 Adult +22 Pupils & & & 43.7 & 2425.9 & 55.5 & \\
\hline G.22 & 1 Adult + 19 Pupils & & & 40.3 & 2166.0 & 53.8 & \\
\hline F1.17 & 1 Adult +23 Pupils & $\begin{array}{l}23 \text { (laptops) } x \\
60 \mathrm{~W}+250 \mathrm{~W}\end{array}$ & & 45.5 & 3899.3 & 85.7 & \\
\hline F1.18 & 1 Adult +20 Pupils & \multirow{6}{*}{$250 W$} & & 38.7 & 2227.6 & 57.5 & \\
\hline F1.19 & 1 Adult + 27 Pupils & & & 52.0 & 2883.8 & 55.5 & \\
\hline F1.20 & 1 Adult +20 Pupils & & & 39.2 & 2232.8 & 56.9 & \\
\hline S2.07 & 1 Adult + 18 Pupils & & & 34.6 & 2036.2 & 58.8 & \\
\hline S2.09 & 1 Adult + 18 Pupils & & & 33.2 & 2022.8 & 61.0 & \\
\hline T3.09 & 1 Adult + 18 Pupils & & & 34.1 & 2030.1 & 59.5 & \\
\hline
\end{tabular}

Table 4 The weight cooling degree hours (WCDH) metric for both TRYs and DSYs (the candidate years selected for DSYs are in bracket for both releases)

\begin{tabular}{|c|c|c|c|c|c|c|c|}
\hline \multirow{3}{*}{ Locations } & \multicolumn{5}{|c|}{ WCDHs (selected year) } & \multirow{2}{*}{\multicolumn{2}{|c|}{2006 release }} \\
\hline & & & 2016 relea & & & & \\
\hline & TRY & pDSY-1(2020) & pDSY-1 & pDSY-2 & pDSY-3 & TRY & DSY \\
\hline Belfast & 0 & 51 & $28(2003)$ & 135 (2006) & 97 (1995) & 0 & 37 (1999) \\
\hline Birmingham & 340 & 1120 & 765 (1989*) & $1890(2006)$ & 1966 (1995) & 534 & 768 (1989*) \\
\hline Cardiff & 144 & 262 & $156(2013)$ & 511 (1995) & 966 (1976) & 49 & $44(1988)$ \\
\hline Edinburgh & 0 & 162 & 109 (1989) & 299 (1975) & $110(2006)$ & 48 & 48 (1997) \\
\hline Glasgow & 12 & 232 & $150(2003)$ & 357 (1975) & 346 (1976) & 2 & 42 (1997) \\
\hline Leeds & 314 & 727 & 486 (1989) & 1356 (1990) & $1336\left(1995^{*}\right)$ & 173 & $1341\left(1995^{*}\right)$ \\
\hline London - Gatwick & - & 1899 & 1201 (1989) & $2984(2003)$ & 3547 (1976) & - & - \\
\hline London - Heathrow & 629 & 2785 & 1808(1989*) & $3146(2003)$ & 3972 (1976) & 886 & 1816 (1989*) \\
\hline London - WC & - & 1777 & 1105 (1989) & 3133 (2003) & $2920(1976)$ & - & - \\
\hline Manchester & 146 & 481 & 282 (1997) & 970 (1990) & 1326 (1995) & 392 & 315 (1999) \\
\hline Newcastle & 85 & 248 & 176 (1996) & 514 (1990) & 185 (2006) & 135 & 10 (1999) \\
\hline Norwich & 836 & 1069 & 670 (1997) & 1332 (1990) & 2330 (1976) & 361 & 135 (2004) \\
\hline Nottingham & 482 & 1295 & 963 (1996) & 1432 (1990) & 1951 (1976) & 152 & $158(2002)$ \\
\hline Plymouth & 24 & 162 & 94 (1984) & 267 (1990*) & $529(1976)$ & 2 & 259 (1990*) \\
\hline Southampton & 187 & 1053 & 645 (1989) & $1170(2003)$ & 2061 (1995) & 258 & $58(1982)$ \\
\hline Swindon & 239 & 1125 & 780 (2013) & $1683(2003)$ & 2320 (1995) & 230 & 248 (1999) \\
\hline
\end{tabular}

*These individual years appear in both releases. Their WCDHs should, in theory, be exactly the same. Close examinations on these weather years indicate that the dry bulb temperatures have been shifted an hour between the two releases for some reason, which led to the slight differences of WCDHs. 
Table 5 Indoor comfort examination using criteria from BB101 2006

\begin{tabular}{|c|c|c|c|c|c|c|c|c|c|c|c|}
\hline \multirow{3}{*}{ Rooms } & \multicolumn{11}{|c|}{ Criteria 1 - Number of Hours over $28 \mathrm{C}$ (Target is $\leq 120$ hours) } \\
\hline & \multicolumn{2}{|c|}{ London TRYs } & \multicolumn{3}{|c|}{ Gatwick DSYs } & \multicolumn{3}{|c|}{ Heathrow DSYs } & \multicolumn{3}{|c|}{ Weather Centre DSYs } \\
\hline & TRY06 & TRY16 & pDSY-1 & pDSY-2 & pDSY-3 & pDSY-1 & pDSY-2 & pDSY-3 & pDSY-1 & pDSY-2 & pDSY-3 \\
\hline G 02 & 15 & 15 & 30 & 46 & 72 & 41 & 65 & 83 & 37 & 66 & 76 \\
\hline G 20 & 77 & 52 & 110 & 102 & 135 & 142 & 158 & 182 & 147 & 175 & 175 \\
\hline G 22 & 57 & 34 & 74 & 82 & 103 & 110 & 132 & 154 & 118 & 142 & 147 \\
\hline F 117 & 47 & 39 & 98 & 123 & 130 & 137 & 149 & 168 & 123 & 152 & 142 \\
\hline F 118 & 32 & 23 & 42 & 70 & 98 & 70 & 92 & 112 & 62 & 96 & 109 \\
\hline F 119 & 16 & 15 & 31 & 48 & 76 & 43 & 65 & 85 & 37 & 67 & 81 \\
\hline F 120 & 15 & 13 & 28 & 44 & 73 & 39 & 63 & 83 & 29 & 64 & 79 \\
\hline S 207 & 21 & 18 & 38 & 60 & 87 & 64 & 83 & 104 & 62 & 89 & 94 \\
\hline S 209 & 28 & 20 & 44 & 65 & 95 & 68 & 95 & 113 & 65 & 94 & 109 \\
\hline Т 309 & 14 & 16 & 31 & 55 & 82 & 57 & 72 & 95 & 51 & 74 & 87 \\
\hline \multirow{3}{*}{ Rooms } & \multicolumn{11}{|c|}{ Criteria 2 - Average internal/external temperature difference (target is $\leq 5^{\circ} \mathrm{C}$ ) } \\
\hline & \multicolumn{2}{|c|}{\begin{tabular}{|l} 
London TRYs \\
\end{tabular}} & \multicolumn{3}{|c|}{ Gatwick DSYs } & \multicolumn{3}{|c|}{ Heathrow DSYs } & \multicolumn{3}{|c|}{ Weather Centre DSYs } \\
\hline & TRY06 & TRY16 & pDSY-1 & pDSY-2 & pDSY-3 & pDSY-1 & pDSY-2 & pDSY-3 & pDSY-1 & pDSY-2 & pDSY-3 \\
\hline G 02 & 3.36 & 3.84 & 3.48 & 3.01 & 3.29 & 3.74 & 3.62 & 3.65 & 3.92 & 3.96 & 3.79 \\
\hline G 20 & 3.45 & 3.74 & 3.39 & 2.85 & 3.07 & 3.83 & 3.63 & 3.70 & 4.06 & 4.12 & 3.88 \\
\hline G 22 & 3.16 & 3.45 & 2.99 & 2.41 & 2.71 & 3.42 & 3.24 & 3.32 & 3.65 & 3.72 & 3.51 \\
\hline F 117 & 4.71 & 5.85 & 5.73 & 5.59 & 5.57 & $\underline{6.07}$ & 5.69 & 5.79 & 5.75 & 5.99 & 5.47 \\
\hline F 118 & 4.66 & 4.96 & 4.97 & 4.31 & 4.76 & 5.18 & 4.87 & 5.05 & 5.24 & 5.13 & 5.12 \\
\hline F 119 & 3.51 & 3.81 & 3.66 & 3.17 & 3.45 & 3.89 & 3.58 & 3.74 & 3.89 & 3.89 & 3.74 \\
\hline $\mathrm{F} 120$ & 3.08 & 3.39 & 3.18 & 2.70 & 2.95 & 3.44 & 3.16 & 3.29 & 3.48 & 3.49 & 3.32 \\
\hline S 207 & 4.48 & 4.95 & 4.68 & 4.31 & 4.51 & 4.94 & 4.74 & 4.84 & 4.99 & 5.12 & 4.71 \\
\hline S 209 & 4.85 & 5.20 & 5.13 & 4.64 & 5.04 & 5.32 & 5.14 & 5.32 & 5.36 & 5.41 & 5.35 \\
\hline Т 309 & 4.29 & 4.66 & 4.51 & 4.16 & 4.27 & 4.81 & 4.35 & 4.54 & 4.59 & 4.73 & 4.30 \\
\hline \multirow{3}{*}{ Rooms } & \multicolumn{11}{|c|}{ Criteria 3-Maxim } \\
\hline & \multicolumn{2}{|c|}{ London TRYs } & \multicolumn{3}{|c|}{ Gatwick DSYs } & \multicolumn{3}{|c|}{ Heathrow DSYs } & \multicolumn{3}{|c|}{ Weather Centre DSYs } \\
\hline & TRY06 & TRY16 & pDSY-1 & pDSY-2 & pDSY-3 & pDSY-1 & pDSY-2 & pDSY-3 & pDSY-1 & pDSY-2 & pDSY-3 \\
\hline G 02 & 31.71 & 31.24 & 33.71 & 35.57 & 34.09 & 33.58 & 36.74 & 34.76 & 33.33 & 37.66 & 34.84 \\
\hline G 20 & 34.29 & 34.64 & 36.75 & 36.87 & 36.94 & 36.64 & 39.57 & 37.81 & 36.6 & $\underline{40.58}$ & 38.01 \\
\hline G 22 & 33.72 & 33.90 & 35.83 & 35.79 & 36.13 & 35.74 & 38.66 & 37.00 & 35.70 & 39.67 & 37.20 \\
\hline $\mathrm{F} 117$ & 32.69 & 33.79 & 36.00 & 38.24 & 36.87 & 35.94 & 39.01 & 37.45 & 35.46 & $\underline{40.10}$ & 37.36 \\
\hline F 118 & 32.88 & 32.93 & 35.14 & 37.17 & 35.69 & 35.19 & 38.42 & 36.59 & 34.61 & 39.35 & 36.54 \\
\hline F 119 & 31.86 & 31.38 & 34.03 & 36.24 & 34.29 & 33.86 & 37.05 & 35.12 & 33.57 & 37.92 & 35.14 \\
\hline $\mathrm{F} 120$ & 31.62 & 31.14 & 33.64 & 35.61 & 33.99 & 33.51 & 36.62 & 34.78 & 33.29 & 37.51 & 34.81 \\
\hline S 207 & 31.85 & 31.75 & 33.94 & 36.14 & 34.69 & 33.88 & 37.09 & 35.50 & 33.54 & 38.04 & 35.57 \\
\hline S 209 & 32.25 & 32.06 & 34.33 & 36.55 & 35.14 & 34.27 & 37.55 & 36.06 & 34.01 & 38.38 & 36.20 \\
\hline T 309 & 31.49 & 31.21 & 33.43 & 35.81 & 34.14 & 33.48 & 36.62 & 34.74 & 33.08 & 37.63 & 34.99 \\
\hline
\end{tabular}


Table 6 Indoor comfort examination using criteria from BB101 $2016 \underline{2018}$

\begin{tabular}{|c|c|c|c|c|c|c|c|c|c|c|c|c|c|c|}
\hline \multirow{3}{*}{ Rooms } & \multicolumn{14}{|c|}{ Criteria $1-$ Hours of Exceedance $\left(H_{e}\right) \leq 40$ hours } \\
\hline & \multicolumn{2}{|c|}{ London TRYs } & \multicolumn{4}{|c|}{ Gatwick DSYs } & \multicolumn{4}{|c|}{ Heathrow DSYs } & \multicolumn{4}{|c|}{ Weather Centre DSYs } \\
\hline & TRY06 & TRY16 & 2020 & -1 & -2 & -3 & 2020 & -1 & -2 & -3 & 2020 & -1 & -2 & -3 \\
\hline G 02 & 10 & 9 & 33 & 24 & 35 & 55 & 41 & 30 & 47 & 56 & 36 & 22 & 42 & 47 \\
\hline G 20 & 63 & 42 & 129 & 96 & 84 & 113 & 149 & 119 & 118 & 135 & 149 & 114 & 127 & 125 \\
\hline G 22 & 45 & 30 & 90 & 54 & 63 & 81 & 114 & 79 & 96 & 98 & 113 & 80 & 98 & 96 \\
\hline $\mathrm{F} 117$ & 39 & 33 & 130 & 89 & 107 & 118 & 154 & 116 & 120 & 125 & 137 & 93 & 118 & 108 \\
\hline $\mathrm{F} 118$ & 33 & 18 & 65 & 42 & 71 & 80 & 84 & 51 & 74 & 84 & 68 & 47 & 69 & 76 \\
\hline F 119 & 12 & 10 & 35 & 26 & 38 & 59 & 44 & 33 & 49 & 59 & 39 & 25 & 45 & 55 \\
\hline $\mathrm{F} 120$ & 10 & 9 & 30 & 20 & 32 & 54 & 38 & 23 & 44 & 54 & 33 & 20 & 38 & 48 \\
\hline S 207 & 15 & 13 & 41 & 32 & 49 & 64 & 60 & 40 & 57 & 69 & 54 & 32 & 60 & 63 \\
\hline S 209 & 21 & 17 & 55 & 36 & 57 & 79 & 78 & 47 & 69 & 81 & 63 & 42 & 68 & 74 \\
\hline T 309 & 10 & 11 & 38 & 26 & 41 & 60 & 50 & 33 & 50 & 62 & 44 & 22 & 47 & 52 \\
\hline \multirow{3}{*}{ Rooms } & \multicolumn{14}{|c|}{ Criteria $2-$ Daily weighted exceedance $\left(W_{e}\right) \leq 6$ degree hours } \\
\hline & \multicolumn{2}{|c|}{ London TRYs } & \multicolumn{4}{|c|}{ Gatwick DSYs } & \multicolumn{4}{|c|}{ Heathrow DSYs } & \multicolumn{4}{|c|}{ Weather Centre DSYs } \\
\hline & TRY06 & TRY16 & 2020 & -1 & -2 & -3 & 2020 & -1 & -2 & -3 & 2020 & -1 & -2 & -3 \\
\hline G 02 & 14 & 11 & 25 & 19 & 22 & 23 & 22 & 19 & 31 & 19 & 21 & 16 & 36 & 21 \\
\hline G 20 & 23 & 25 & 38 & 34 & 27 & 34 & 35 & 32 & 43 & 34 & 35 & 31 & 50 & 38 \\
\hline G 22 & 22 & 19 & 33 & 28 & 22 & 29 & 32 & 26 & 37 & 30 & 29 & 27 & 44 & 32 \\
\hline $\mathrm{F} 117$ & 20 & 25 & 39 & 34 & 39 & 42 & 38 & 32 & 49 & 40 & 35 & 30 & 51 & 41 \\
\hline $\mathrm{F} 118$ & 21 & 19 & 35 & 29 & 34 & 33 & 32 & 25 & 42 & 28 & 30 & 25 & 45 & 32 \\
\hline F 119 & 14 & 11 & 26 & 22 & 27 & 24 & 25 & 19 & 31 & 21 & 22 & 18 & 36 & 23 \\
\hline $\mathrm{F} 120$ & 14 & 10 & 24 & 19 & 23 & 22 & 20 & 18 & 31 & 19 & 21 & 16 & 32 & 21 \\
\hline S 207 & 14 & 13 & 26 & 22 & 27 & 28 & 25 & 20 & 36 & 27 & 23 & 18 & 38 & 28 \\
\hline S 209 & 18 & 17 & 29 & 24 & 29 & 31 & 27 & 22 & 40 & 28 & 26 & 22 & 41 & 32 \\
\hline T 309 & 12 & 11 & 23 & 19 & 24 & 24 & 23 & 18 & 33 & 21 & 20 & 16 & 35 & 23 \\
\hline \multirow{3}{*}{ Rooms } & \multicolumn{14}{|c|}{ Criteria 3 - Upper limit temperature $\left(T_{\text {upp }}\right)$, with condition $\Delta T=T_{\text {upp }}-T_{\max } \leq 4 \mathrm{~K}$} \\
\hline & \multicolumn{2}{|c|}{ London TRYs } & \multicolumn{4}{|c|}{ Gatwick DSYs } & \multicolumn{4}{|c|}{ Heathrow DSYs } & \multicolumn{4}{|c|}{ Weather Centre DSYs } \\
\hline & TRY06 & TRY16 & 2020 & -1 & -2 & -3 & 2020 & -1 & -2 & -3 & 2020 & -1 & -2 & -3 \\
\hline G 02 & 4 & 3 & 6 & 5 & 6 & 5 & 5 & 5 & 7 & 5 & 5 & 4 & 8 & 5 \\
\hline G 20 & 6 & 6 & 9 & 8 & 8 & 8 & 8 & 8 & 10 & 8 & 8 & 8 & 11 & 8 \\
\hline G 22 & 6 & 5 & 8 & 7 & 7 & 7 & 8 & 7 & 9 & 7 & 7 & 7 & 10 & 7 \\
\hline $\mathrm{F} 117$ & 5 & 5 & 8 & 7 & 9 & 8 & 8 & 7 & 9 & 8 & 7 & 7 & 10 & 8 \\
\hline F 118 & 5 & 5 & 8 & 7 & 8 & 7 & 7 & 6 & 9 & 7 & 7 & 6 & 10 & 7 \\
\hline $\mathrm{F} 119$ & 4 & 3 & 6 & 6 & 7 & 5 & 6 & 5 & 7 & 6 & 5 & 5 & 8 & 6 \\
\hline $\mathrm{F} 120$ & 4 & 3 & 6 & 5 & 6 & 5 & 5 & 5 & 7 & 5 & 5 & 4 & 7 & 5 \\
\hline S 207 & 4 & 3 & 6 & 5 & 7 & 6 & 6 & 5 & 7 & 6 & 5 & 5 & 8 & 6 \\
\hline S 209 & 4 & 4 & 6 & 6 & 7 & 6 & 6 & 5 & 8 & 7 & 6 & 5 & 8 & 7 \\
\hline T 309 & 3 & 3 & 5 & 5 & 6 & 5 & 5 & 4 & 7 & 5 & 5 & 4 & 7 & 5 \\
\hline
\end{tabular}


2

Table 7 Indoor $\mathrm{CO}_{2}$ concentration examination using criteria from BB101 2006 \& 20162018.

\begin{tabular}{|c|c|c|c|c|c|c|c|c|c|c|c|c|c|c|}
\hline \multirow{3}{*}{ Rooms } & \multicolumn{14}{|c|}{ Maximum $\mathrm{CO}_{2}$ concentration: Target $\leq 5000 \mathrm{ppm}(\mathrm{BB} 1012006) ; \leq 2000 \mathrm{ppm}(\mathrm{BB} 1012018)$} \\
\hline & \multicolumn{2}{|c|}{ London TRYs } & \multicolumn{4}{|c|}{ Gatwick DSYs } & \multicolumn{4}{|c|}{ Heathrow DSYs } & \multicolumn{4}{|c|}{ Weather Centre DSYS } \\
\hline & TRY06 & TRY16 & 2020 & -1 & -2 & -3 & 2020 & -1 & -2 & -3 & 2020 & \begin{tabular}{|l|}
-1 \\
\end{tabular} & -2 & -3 \\
\hline G 02 & 2627 & 1851 & 2021 & 2012 & 2144 & 2170 & 1837 & 1839 & 2021 & 2753 & 1916 & 1913 & 1886 & 1914 \\
\hline G 20 & 1745 & 1389 & 1528 & 1573 & 1886 & 1687 & 1337 & 1393 & 1423 & 1347 & 1340 & 1343 & 1343 & 1351 \\
\hline G 22 & 1708 & 1331 & 1740 & 1711 & 1773 & 1730 & 1322 & 1310 & 1362 & 1284 & 1260 & 1274 & 1280 & 1286 \\
\hline F 117 & 1115 & 114 & 1001 & 1070 & 1294 & 1126 & 952 & 958 & 1137 & 1081 & 898 & 993 & 1074 & 68 \\
\hline F 118 & 1853 & 18 & 1537 & 1936 & 1980 & 1888 & 1219 & 1522 & 1625 & 1543 & 1244 & 1549 & 1545 & 15 \\
\hline F 119 & 1475 & & 1503 & 1513 & 1645 & 1506 & 1471 & 1470 & 1520 & 1476 & 1450 & 1448 & 1501 & 14 \\
\hline F 120 & 1399 & & 1422 & 142 & 1562 & 1423 & 1371 & 1369 & 1413 & 1402 & 1346 & 50 & 1397 & 92 \\
\hline S 207 & 363 & & 1139 & & 2453 & 1937 & 1061 & 39 & 1777 & 1552 & 1050 & & 1171 & \\
\hline S 209 & 27 & & 1097 & & 2335 & 2168 & 1005 & 1091 & 1582 & 1223 & 991 & & 1103 & 16 \\
\hline T309 & 340 & 2224 & 1161 & 1614 & 2120 & 1758 & 1031 & 1077 & 1786 & 1925 & 1032 & 1189 & 1387 & \\
\hline \multirow{3}{*}{ Rooms } & \multicolumn{14}{|c|}{ Maximum daily average $\mathrm{CO}_{2}$ : Target $\leq 1500 p p m$ (BB101 2006); $\leq 1000 p p m$ (BB101 2018) } \\
\hline & \multicolumn{2}{|c|}{ London TRYs } & \multicolumn{4}{|c|}{ Gatwick DSYs } & \multicolumn{4}{|c|}{ Heathrow DSYs } & \multicolumn{4}{|c|}{ Weather Centre DSYs } \\
\hline & TRY06 & TRY16 & 2020 & -1 & -2 & -3 & 2020 & -1 & -2 & -3 & 2020 & -1 & -2 & -3 \\
\hline G 02 & 1454 & 1393 & 1250 & 1371 & 1399 & 1481 & 1096 & 1210 & 1256 & 1230 & 1152 & 1283 & 1160 & 1221 \\
\hline G 20 & 1179 & 1137 & 1282 & 1283 & 1445 & 1287 & 1116 & 1126 & 1154 & 1130 & 1109 & 1117 & 1136 & 1118 \\
\hline G 22 & 1109 & 1086 & 1292 & 1302 & 1386 & 1262 & 1069 & 1077 & 1106 & 1086 & 1067 & 1073 & 1088 & 1073 \\
\hline F 117 & 866 & 989 & 766 & 812 & 944 & 901 & 724 & 773 & 826 & 853 & 745 & 805 & 799 & 839 \\
\hline F 118 & 1112 & 1218 & 987 & 1092 & 1176 & 1077 & 859 & 971 & 986 & 1014 & 857 & 990 & 910 & 1022 \\
\hline F 119 & 1181 & 1225 & 1069 & 1157 & 1180 & 1221 & 995 & 1073 & 1081 & 1101 & 979 & 1067 & 1028 & 1134 \\
\hline F 120 & 1161 & 1158 & 1134 & 1194 & 1234 & 1179 & 1047 & 1103 & 1106 & 1116 & 1022 & 1096 & 1067 & 1108 \\
\hline S 207 & 1156 & 1283 & 939 & 1065 & 1389 & 1216 & 905 & 976 & 1084 & 1030 & 867 & 928 & 929 & 1079 \\
\hline S 209 & 1114 & 1273 & 927 & 1051 & 1344 & 1128 & 852 & 908 & 967 & 964 & 835 & 901 & 916 & 956 \\
\hline T 309 & 1169 & 1515 & 919 & 1035 & 1280 & 1346 & 866 & 919 & 1037 & 1186 & 806 & 872 & 933 & 1228 \\
\hline
\end{tabular}


Table A1. List of ventilation openings and their characteristics ( $\mathrm{Cd}$ is the discharge coefficients)

\begin{tabular}{|c|c|c|c|c|}
\hline Room & Opening Type & Free Area $\left(\mathrm{m}^{2}\right)$ & Cd & Opening Period \\
\hline G02 & \begin{tabular}{|l|}
1 No. Louvre (inlet) \\
1 No. Transfer Louvre \\
1 No. Airstract ${ }^{* 1}$ (Roof terminal) \\
3 No. Openable windows ${ }^{*}$
\end{tabular} & $\begin{array}{c}0.112 \\
0.192 \\
0.368 \\
4.3\end{array}$ & $\begin{array}{c}0.4 \\
0.55 \\
0.61 \\
0.61\end{array}$ & $\begin{array}{l}\text { 09:00 to } 15: 30, \text { Mon To Fri }{ }^{{ }^{2}} \\
\text { 00:00 to } 24: 00 \text {, Mon to Sun } \\
\text { 00:00 to } 24: 00 \text {, Mon to Sun } \\
\text { 09:00 to } 15: 30 \text {, Mon To Fri }{ }^{* 3}\end{array}$ \\
\hline G20 & $\begin{array}{l}8 \text { No. Louvre (inlet) } \\
1 \text { No. Transfer Louvre } \\
2 \text { No. Louvre (exhaust) } \\
0 \text { No. Openable windows }{ }^{* 4} \\
\end{array}$ & $\begin{array}{c}0.136 \text { by } 8 \\
0.201 \\
0.274 \text { by } 2 \\
- \\
\end{array}$ & $\begin{array}{c}0.4 \\
0.55 \\
0.4 \\
0.61 \\
\end{array}$ & $\begin{array}{l}\text { 09:00 to } 15: 30, \text { Mon To Fri }{ }^{{ }^{2}} \\
\text { 00:00 to } 24: 00 \text {, Mon to Sun } \\
\text { 00:00 to } 24: 00, \text { Mon to Sun } \\
\text { 09:00 to } 15: 30 \text {, Mon To Fri }{ }^{* 3}\end{array}$ \\
\hline G22 & $\begin{array}{l}8 \text { No. Louvre (inlet) } \\
1 \text { No. Transfer Louvre } \\
2 \text { No. Louvre (exhaust) } \\
0 \text { No. Openable windows }{ }^{*}\end{array}$ & $\begin{array}{c}0.136 \text { by } 8 \\
0.201 \\
0.274 \text { by } 2 \\
- \\
\end{array}$ & $\begin{array}{c}0.4 \\
0.55 \\
0.4 \\
0.61 \\
\end{array}$ & $\begin{array}{l}\text { 09:00 to } 15: 30, \text { Mon To Fri }{ }^{{ }^{2}} \\
\text { 00:00 to } 24: 00, \text { Mon to Sun } \\
\text { 00:00 to } 24: 00, \text { Mon to Sun } \\
\text { 09:00 to } 15: 30, \text { Mon To Fri }{ }^{{ }^{3}}\end{array}$ \\
\hline F117 & $\begin{array}{l}1 \text { No. Louvre (inlet) } \\
1 \text { No. Transfer Louvre } \\
1 \text { No. Airstract }{ }^{* 1} \text { (Roof terminal) } \\
4 \text { No. Openable windows }{ }^{*}\end{array}$ & $\begin{array}{c}0.112 \\
0.201 \\
0.368 \\
3.08\end{array}$ & $\begin{array}{c}0.4 \\
0.55 \\
0.4 \\
0.61\end{array}$ & $\begin{array}{l}\text { 09:00 to } 15: 30, \text { Mon To Fri }{ }^{* 2} \\
\text { 00:00 to } 24: 00 \text {, Mon to Sun } \\
\text { 00:00 to } 24: 00 \text {, Mon to Sun } \\
\text { 09:00 to } 15: 30 \text {, Mon To Fri }{ }^{* 3}\end{array}$ \\
\hline F118 & $\begin{array}{l}1 \text { No. Louvre (inlet) } \\
1 \text { No. Transfer Louvre } \\
2 \text { No. Louvre (exhaust) } \\
4 \text { No. Openable windows }{ }^{*} \\
\end{array}$ & $\begin{array}{c}0.112 \\
0.201 \\
0.238 \text { by } 2 \\
3.89 \\
\end{array}$ & $\begin{array}{c}0.4 \\
0.55 \\
0.4 \\
0.61 \\
\end{array}$ & $\begin{array}{l}\text { 09:00 to } 15: 30, \text { Mon To Fri }{ }^{* 2} \\
\text { 00:00 to } 24: 00 \text {, Mon to Sun } \\
\text { 00:00 to } 24: 00, \text { Mon to Sun } \\
\text { 09:00 to } 15: 30, \text { Mon To Fri }{ }^{* 3}\end{array}$ \\
\hline F119 & $\begin{array}{l}1 \text { No. Louvre (inlet) } \\
1 \text { No. Transfer Louvre } \\
2 \text { No. Louvre (exhaust) } \\
6 \text { No. Openable windows }{ }^{*}{ }^{2}\end{array}$ & $\begin{array}{c}0.112 \\
0.201 \\
0.238 \text { by } 2 \\
5.73\end{array}$ & $\begin{array}{c}0.4 \\
0.55 \\
0.4 \\
0.61\end{array}$ & $\begin{array}{l}\text { 09:00 to } 15: 30, \text { Mon To Fri }{ }^{{ }^{2}} \\
\text { 00:00 to } 24: 00 \text {, Mon to Sun } \\
\text { 00:00 to } 24: 00 \text {, Mon to Sun } \\
\text { 09:00 to } 15: 30 \text {, Mon To Fri }{ }^{* 3}\end{array}$ \\
\hline F120 & $\begin{array}{l}1 \text { No. Louvre (inlet) } \\
1 \text { No. Transfer Louvre } \\
2 \text { No. Louvre (exhaust) } \\
4 \text { No. Openable windows }{ }^{*} \\
\end{array}$ & $\begin{array}{c}0.112 \\
0.201 \\
0.238 \text { by } 2 \\
3.89 \\
\end{array}$ & $\begin{array}{c}0.4 \\
0.55 \\
0.4 \\
0.61 \\
\end{array}$ & $\begin{array}{l}\text { 09:00 to } 15: 30, \text { Mon To Fri }{ }^{* 2} \\
\text { 00:00 to } 24: 00 \text {, Mon to Sun } \\
\text { 00:00 to } 24: 00, \text { Mon to Sun } \\
\text { 09:00 to } 15: 30, \text { Mon To Fri }{ }^{{ }^{3}}\end{array}$ \\
\hline S207 & $\begin{array}{l}1 \text { No. Louvre (inlet) } \\
1 \text { No. Transfer Louvre } \\
1 \text { No. Airstract }{ }^{*} \text { (Roof terminal) }^{*}{ }_{4} \\
4 \text { No. Openable windows }\end{array}$ & $\begin{array}{c}0.112 \\
0.219 \\
0.368 \\
3.08\end{array}$ & $\begin{array}{c}0.4 \\
0.55 \\
0.4 \\
0.61\end{array}$ & $\begin{array}{l}\text { 09:00 to } 15: 30, \text { Mon To Fri }{ }^{* 2} \\
\text { 00:00 to } 24: 00 \text {, Mon to Sun } \\
\text { 00:00 to } 24: 00, \text { Mon to Sun } \\
\text { 09:00 to } 15: 30, \text { Mon To Fri }{ }^{* 3}\end{array}$ \\
\hline S209 & $\begin{array}{l}1 \text { No. Louvre (inlet) } \\
1 \text { No. Transfer Louvre } \\
2 \text { No. Louvre (exhaust) } \\
4 \text { No. Openable windows }{ }^{* 4}\end{array}$ & $\begin{array}{c}0.112 \\
0.219 \\
0.256 \text { by } 2 \\
3.14\end{array}$ & $\begin{array}{c}0.4 \\
0.55 \\
0.4 \\
0.61\end{array}$ & $\begin{array}{l}\text { 09:00 to } 15: 30, \text { Mon To Fri }{ }^{{ }^{2}} \\
\text { 00:00 to } 24: 00 \text {, Mon to Sun } \\
\text { 00:00 to } 24: 00, \text { Mon to Sun } \\
\text { 09:00 to } 15: 30 \text {, Mon To Fri }{ }^{* 3}\end{array}$ \\
\hline T309 & $\begin{array}{l}1 \text { No. Louvre (inlet) } \\
1 \text { No. Transfer Louvre } \\
1 \text { No. Airstract (Roof terminal) } \\
4 \text { No. Openable windows }{ }^{* 4}\end{array}$ & $\begin{array}{c}0.112 \\
0.293 \\
0.384 \\
2.75 \\
\end{array}$ & $\begin{array}{l}0.4 \\
0.55 \\
0.61 \\
0.61 \\
\end{array}$ & $\begin{array}{l}\text { 09:00 to } 15: 30, \text { Mon To Fri }{ }^{* 2} \\
\text { 00:00 to } 24: 00, \text { Mon to Sun } \\
\text { 00:00 to } 24: 00, \text { Mon to Sun } \\
\text { 09:00 to } 15: 30, \text { Mon To Fri }{ }^{* 3}\end{array}$ \\
\hline
\end{tabular}

${ }^{* 1}$ The 1 No. $1250 \times 575$ Airstract was shared by Rooms G02, F117 \& S207.

${ }^{*}$ Aircool Louvre opening controlled between 09:00 and 15:30 Monday to Friday and closed at all other times during the winter period, October to April. Opening varies from fully closed to fully open as the $\mathrm{CO}_{2}$ concentration rises from $800 \mathrm{ppm}$ to $2000 \mathrm{ppm}$. Open at night and at weekends during the summer period, May to September, for night cooling

${ }^{* 3}$ Window opening controlled between 09:00 and 15:30 Monday to Friday and closed at all other times during the summer period, May to September inclusive. Opening varies from fully closed to fully open as the temperature rises from $20^{\circ} \mathrm{C}$ to $24{ }^{\circ} \mathrm{C}$ or the $\mathrm{CO}_{2}$ concentration rises from $800 \mathrm{ppm}$ to $2000 \mathrm{ppm}$

${ }^{*}$ The number counted here is the openable windows, they are either 'tilt and turn' windows or 'bottomhinged' windows. In IES model, the free areas of these windows are the maximum openable areas for these windows. It has been assumed that these areas are achievable in practice. 


\section{Figure List:}

Fig 1 Plan view of the school with surrounding buildings (left), axonometric view of the school (right).

Fig 2 Floor plan views (second and third floors, the narrow extruded parts were cut off)

Figure 3 Internal variables/External dry bulb temperature for a cooler day (left) and a warmer day (right) for room F117 using the TRY 2016 weather data.

Figure $4 \mathrm{CO}_{2}$ concentration, ventilation, and internal/external temperatures for a cooler day (left) and a warmer day (right) for room F117 using the TRY 2016 weather data

Figure 5 Predictions on Hours of Exceedance $H_{e}$ and the number of hours over $28^{\circ} \mathrm{C}$ for the 10 rooms with 11 weather data.

Figure 6 Indoor (operative temperaure, $\mathrm{CO} 2$, solar gain) and outdoor (dry bulb temperature, cloud cover) parameters on the peak date for room F117 with Heathrow pDSY-3 weather data. 

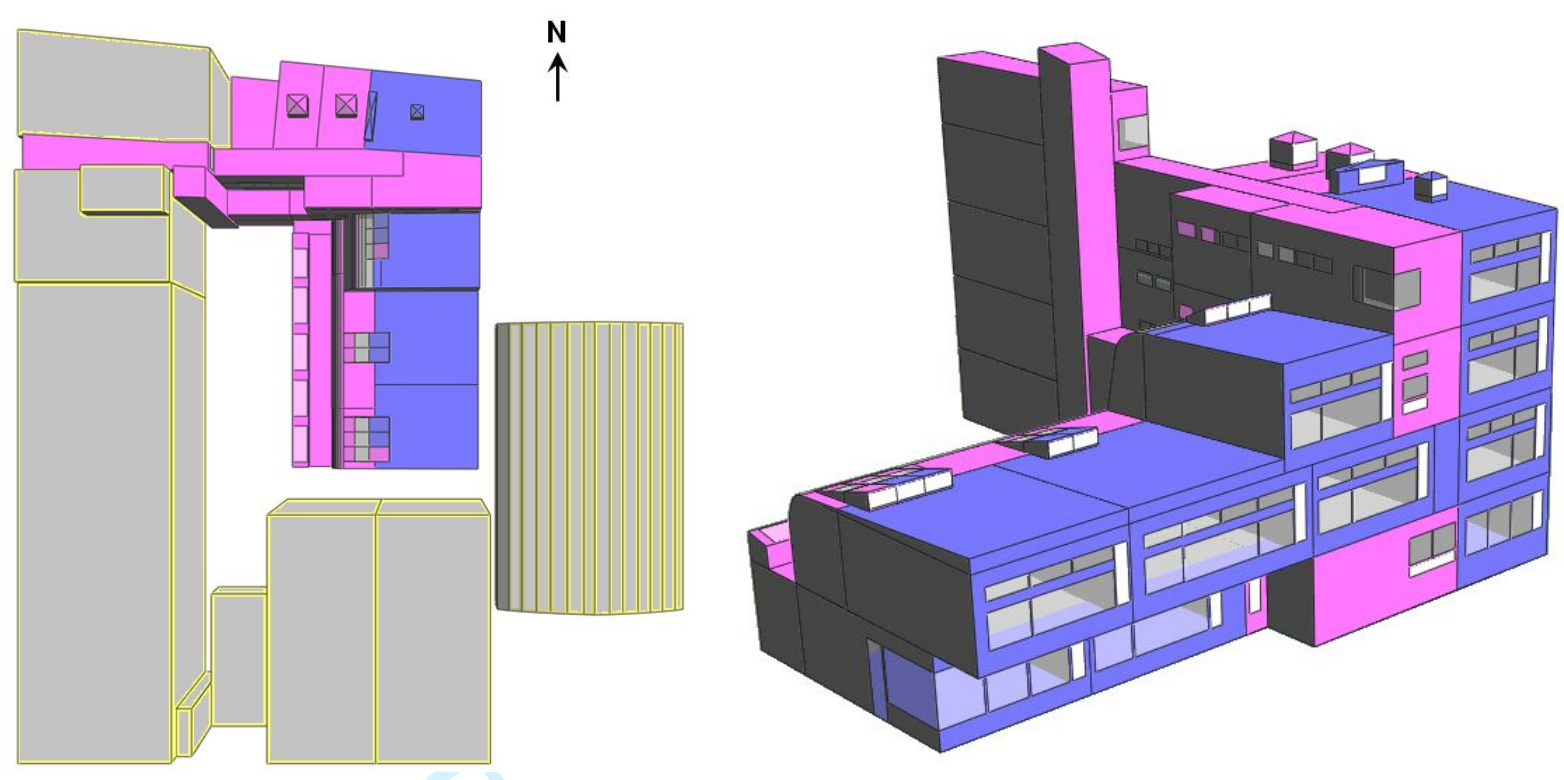

Fig 1 Plan view of the school with surrounding buildings (left), axonometric view of the school (right).
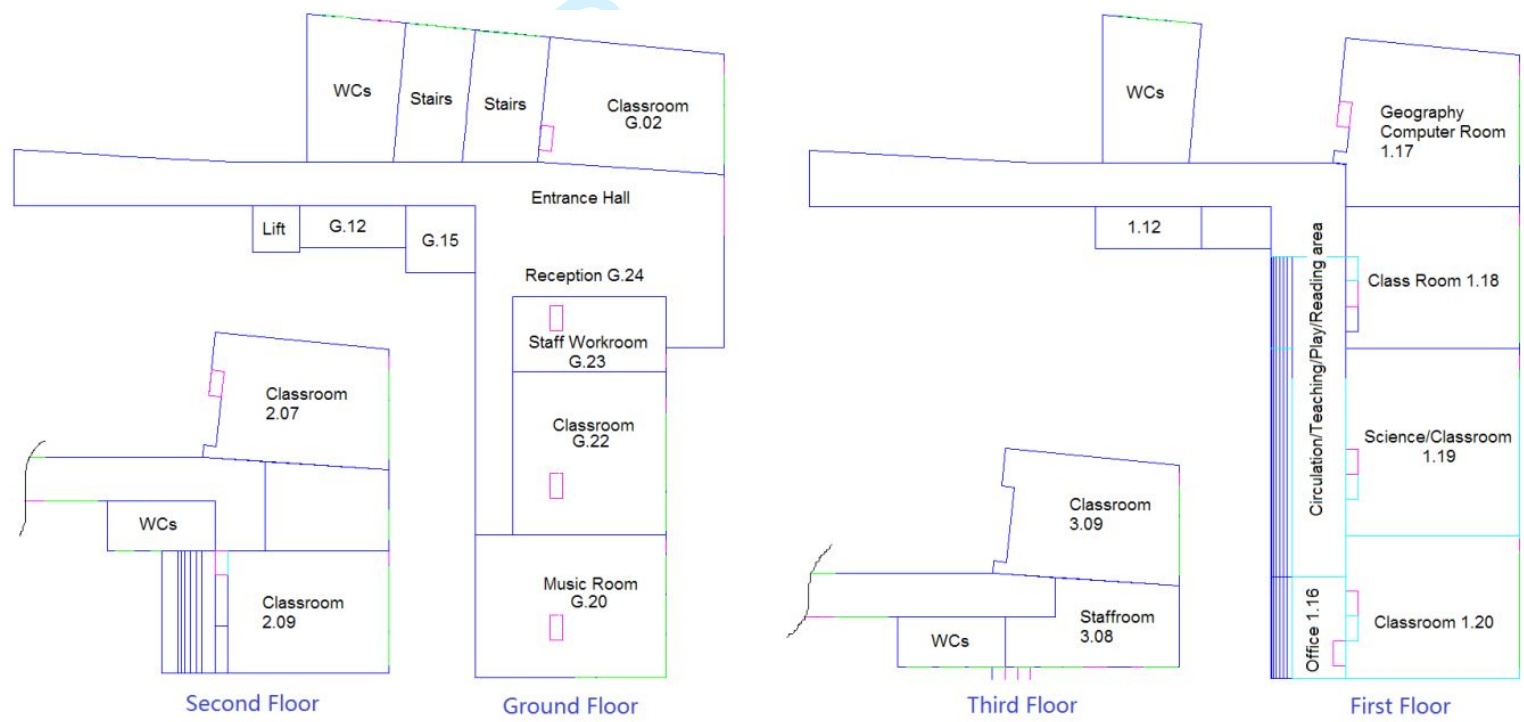

Fig 2 Floor plan views (second and third floors, the narrow extruded parts were cut off) 


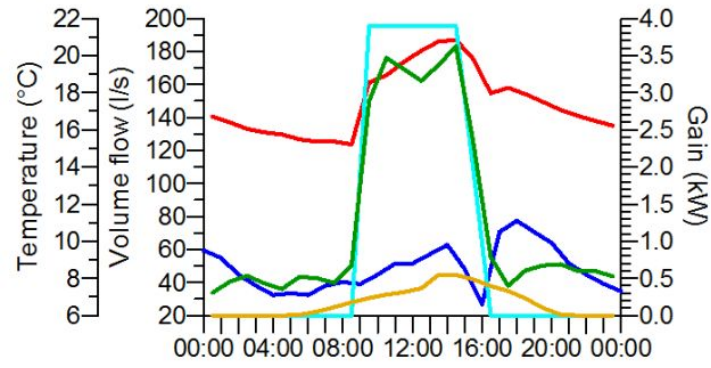

Date: Tue 04/May

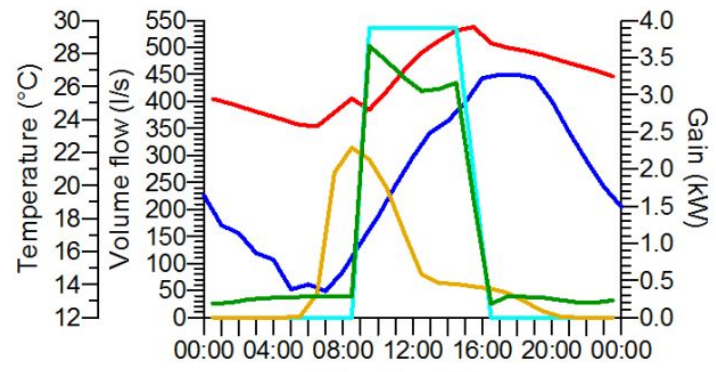

Date: Thu 12/Aug

$\begin{array}{lll}\text { — Air temperature: F117 } & \text { - Internal gain: F 117 - Solar gain: F117 } \\ \text { — Ventilation rate: F117 _ Dry-bulb temperature: (TRY2016) }\end{array}$

Figure 3 Internal variables/External dry bulb temperature for a cooler day (left) and a warmer day (right) for room F117 using the TRY 2016 weather data.

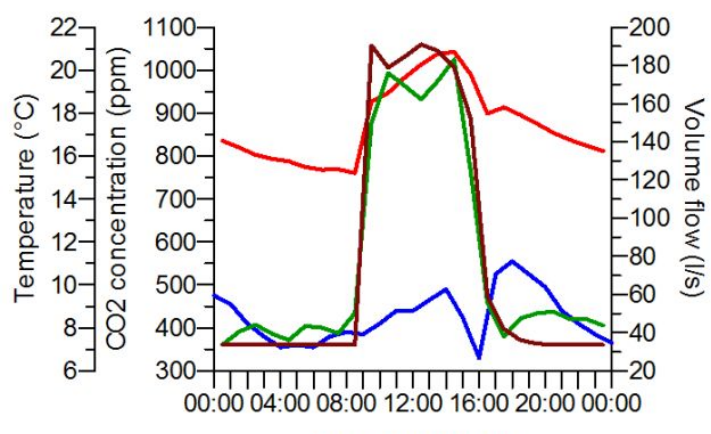

Date: Tue 04/May

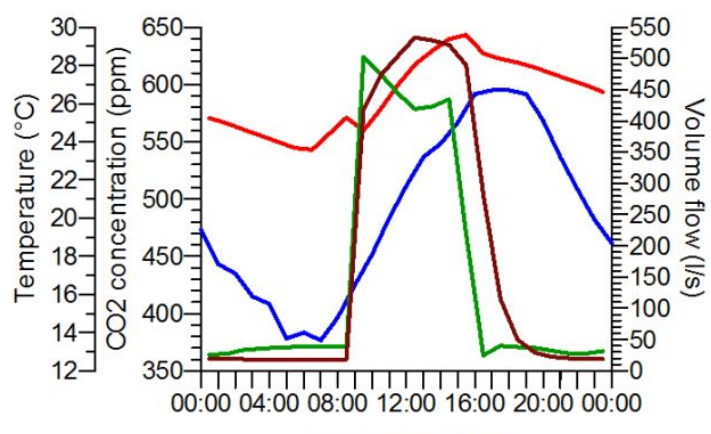

Date: Thu 12/Aug

$$
\begin{array}{ll}
\text { — Air temperature: F117 } & \text { - Ventilation rate : F } 117 \\
\text { — Dry-bulb temperature: (TRY2016) } & \text { — Room CO2 concentration: F } 117
\end{array}
$$

Figure $4 \mathrm{CO}_{2}$ concentration, ventilation, and internal/external temperatures for a cooler day (left) and a warmer day (right) for room F117 using the TRY 2016 weather data

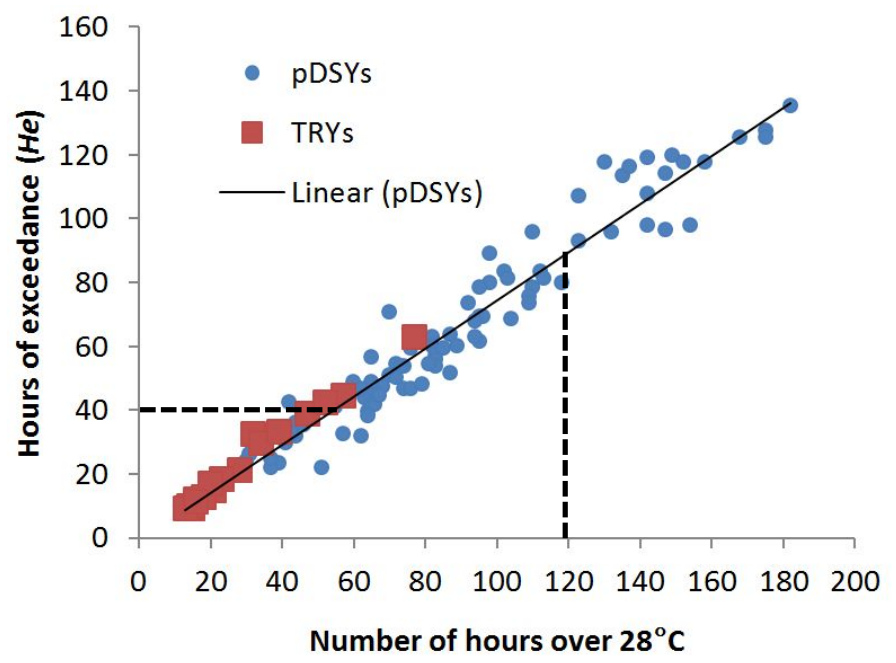

Figure 5 Predictions on Hours of Exceedance $H_{e}$ and the number of hours over $28^{\circ} \mathrm{C}$ for the 10 rooms with 11 weather data. 


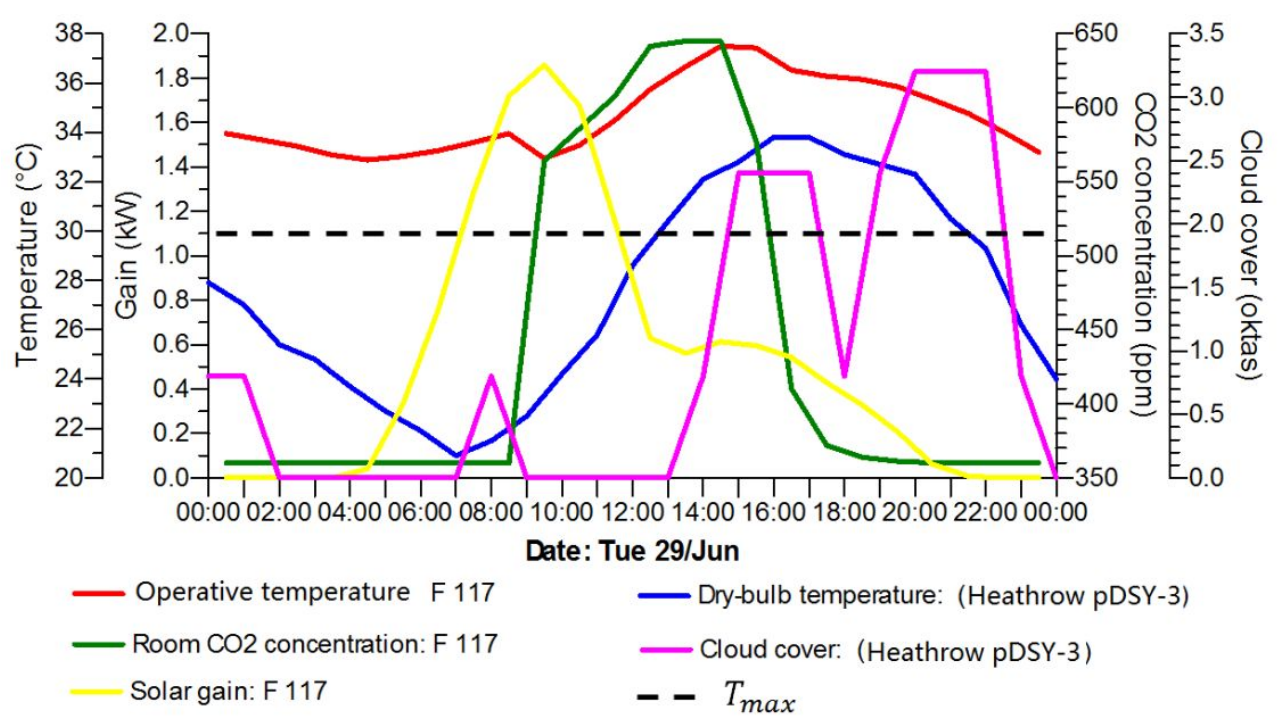

Figure 6 Indoor (operative temperaure, $\mathrm{CO} 2$, solar gain) and outdoor (dry bulb temperature, cloud cover) parameters on the peak date for room F117 with Heathrow pDSY-3 weather data. 